\title{
Controlling for the use of extreme weights in bank efficiency assessments during the financial crisis
}

Article

Accepted Version

Creative Commons: Attribution-Noncommercial-No Derivative Works 4.0

Asmild, M. and Zhu, M. (2016) Controlling for the use of extreme weights in bank efficiency assessments during the financial crisis. European Journal of Operational Research, 251 (3). pp. 999-1015. ISSN 0377-2217 doi:

https://doi.org/10.1016/j.ejor.2015.12.021 Available at https://centaur.reading.ac.uk/69055/

It is advisable to refer to the publisher's version if you intend to cite from the work. See Guidance on citing.

To link to this article DOI: http://dx.doi.org/10.1016/j.ejor.2015.12.021

Publisher: Elsevier

All outputs in CentAUR are protected by Intellectual Property Rights law, including copyright law. Copyright and IPR is retained by the creators or other copyright holders. Terms and conditions for use of this material are defined in the End User Agreement.

www.reading.ac.uk/centaur 
Central Archive at the University of Reading

Reading's research outputs online 


\title{
Controlling for the use of extreme weights in bank efficiency assessments during the financial crisis
}

\author{
Mette Asmild \\ IFRO
University of Copenhagen, Denmark \\ Minyan Zhu \\ Business School \\ University of Nottingham, UK
}

September 25, 2015

\begin{abstract}
We propose a method for bank efficiency assessment, based on weight restricted DEA, that limits banks' abilities to use extreme weights, corresponding to extreme judgements of the risk adjusted prices on funding sources and assets. Based on a data set comprising the largest European banks during the financial crisis, we illustrate the impact of the proposed weight restrictions in two different efficiency models; one related to banks' funding mix and one related to their asset mix. The results show that using a more balanced set of weights tend to reduce the estimated efficiency scores more for those banks which were bailed out during the crisis, which confirms the potential bias within standard DEA that does not control for extreme weights applied by highly risky banks. We discuss the use of the proposed method as a regulatory tool to constrain discretion when complying with regulatory capital benchmarks such as the Basel regulatory capital ratios.
\end{abstract}

Keywords: Data Envelopment Analysis (DEA), weight restrictions, banking, efficiency, risk, financial crisis, regulation, benchmarks.

Correspondence: Mette Asmild, IFRO, University of Copenhagen, Rolighedsvej 25, 1958 Frederiksberg C., Denmark, tel. +45 353368 86, e-mail: meas@ifro.ku.dk 


\section{Introduction and Motivation}

The recent financial crisis made it painfully clear that bank risk can arise from heavy reliance on certain types of funding and/or assets, for example the relative exposure to real estate loans or reliance on wholesale funding. Risk consideration in this respect has not previously been explicitly recognized in the literature assessing bank efficiency. Therefore it is important to understand the implications on bank performance measures, of using extreme rather than well-balanced funding or asset portfolios, as was evidently the case for some banks during the recent crisis.

On an abstract level, the definition of true risk is not immediately clear in the financial literature. Holton (2004) makes this point clear: Risk depends on the notions of exposure and uncertainty, neither of which can be defined operationally. Probabilities quantify perceived uncertainty. The litmus test for exposure is "would we care if we were..."-it is a hypothetical and unobserved test. Therefore, at best, we can operationally define our perception of risk.

In the banking literature, several studies have made significant contributions to the understanding of the nature of banking and perceived risks. For instance, Diamond and Dybvig (1983) explain why bank contracts are less stable than other types of financial contracts: demand deposit contracts allow lenders to withdraw money when needed thus provide liquidity; this service provided by banks of transforming illiquid assets into liquid liabilities leave banks vulnerable to runs which occur because there are multiple equilibria with differing confidence levels. Diamond and Rajan (2001) further demonstrate that this fragile nature associated with bank runs and bank capital structure commits banks to creating liquidity, enabling depositors to withdraw when needed while buffering borrowers from depositors' liquidity needs. Other than liquidity risk, banks also face other types of risks such as default risk arising from default of borrowers and market risk arising from the change of market conditions (such as interest rates, exchange rates etc) resulting in potential losses in banks' trading portfolio. With the rising of structured finance prior to the crisis, a recent study by Coval et al. (2009) demonstrates how during the process of pooling and tranching of structured financial products, the default risk of senior tranches can be concentrated in systematically adverse economic states. They show that this systemic risk exposure is not appropriately priced by investors (which include banks) who invest in structured financial products. This shows banks are often exposed to systemic risks too.

The method proposed in the paper is motivated by identifying bank managers' perceptions of risks (which could be related to all types of risk mentioned above) reflected in their funding structures and asset portfolios, while assessing bank efficiency.

Data Envelopment Analysis (DEA) is often used to assess the efficiency of banks. In the ratio (multiplier) formulation of DEA, efficiency is estimated as the ratio of a 
weighted sum of outputs over a weighted sum of inputs. The weights (multipliers) for the inputs and outputs are free variables in the optimization maximizing the efficiency measure for each bank, subject only to the constraint that the efficiency scores for all banks must be between 0 and 1 when applying those weights. If no further restrictions are imposed on the weights, in order to maximize the efficiency for a bank, high weights are placed on variables it performs relatively well on, for examples outputs it produces a lot of, and low weights are placed on variables it performs relatively poorly on, for example inputs it uses a lot of. Therefore, banks with extreme funding or asset portfolios will also prefer, or be assigned, extreme choices of weights in the efficiency assessment. Furthermore, for a bank with the highest ratio of any one output to any one input in the constant returns to scale (CRS) models employed here, weights can be used that result in the largest possible efficiency score of one and thus such banks become "efficient by default", simply because the extreme funding or asset portfolios means that it cannot really be compared to any other bank(s) in the efficiency assessment ${ }^{1}$. A potentially unfortunate consequence of this characteristic of DEA is that the method implicitly rewards extreme behaviour in terms of the composition of the input- and output portfolios. In some cases, like that of bank performance assessment, extreme inputand output (funding or asset) portfolios are associated with high risks, which should be properly accounted for, rather than necessarily rewarded, in the assessment. Since the weights can be interpreted as relative prices for the inputs and outputs, we argue that a proper choice of weights should also reflect the underlying risks of the variable such that the weights reflect risk adjusted prices. This is particularly pertinent for bank efficiency measurement, since studies have shown that banks' differ wildly in their assessments of the risks associated with certain assets.

In this paper we suggest that weight restrictions should be used in cases like this, to counter the inclination towards choosing extreme weights that do not account for the risk reflected in extreme input- and output portfolios. We specifically consider two different weight restricted DEA models to measure bank performance, where we restrict the weights attached to different types of funding and other inputs, in a model concerning the transformation of funding and other inputs into assets, and also restrict the weights on the different types of loans and other assets in a second model concerning the transformation of assets into income. The (relative) weights are restricted to having to belong to ranges determined from the average (relative) weights used across the efficient facets of the frontier. This way, efficiency scores are obtained by comparing all banks, regardless of their mixes of inputs and outputs in the two models and corresponding differences in preferred weights, to a balanced set of weights. As robustness checks, we also apply weight restrictions based on the average observed unit and furthermore weight restrictions based on the median rather than mean values. As detailed in the following, the contribution of our proposed method comprises two aspects: One related

\footnotetext{
${ }^{1}$ Under the alternative variable returns to scale assumption this problem is actually exacerbated, since any bank with the highest value of any one output or the lowest value on any input will also be efficient by default.
} 
to performance measurement and the other concerning regulation.

In terms of the first contribution of this paper related to bank efficiency measurement, it is important to note that the standard DEA models (c.f. Charnes et al., 1978) commonly used in the literature to measure bank performance (c.f. e.g. Berger and Humphrey, 1997 and Berger, 2007) are not well suited to dealing with bank risks reflected in their asset or funding portfolios, c.f. the discussion above. Despite the fact that standard DEA is the approach most widely used in the literature to measure bank performance, this feature of the DEA models makes it unsatisfactory for the assessment of the performance of banks where the use of extreme input and output portfolios might mean risky behaviour - a problem which has never been more apparent and relevant than during the recent financial crisis.

It is worth noting that restricting weights can make previously efficient funding and asset portfolios inefficient. But we are not proposing that banks should restrict (the mixes within) their input-output portfolios to belonging to specific ranges or that there exists a unique good risk portfolio. Our weight restrictions are indirectly defined from the weights of the efficient banks (via the corresponding fully dimensional efficient facets, c.f. Section 3). So the set of restricted weights depends on the average risk judgement of all included banks; it is not a pre-determined or unique set. Using the actual crisis as our context, we are proposing that when evaluating efficiency in the banking sector, balanced risk judgements are preferred to extreme risk judgements at the practice level. Different sets of weight restrictions can be used in different contexts to achieve the purpose of measuring bank efficiency without being biased by banks' extreme risk judgements. As rightly pointed out by Thanassoulis and Allen (1998), also in the context of weight restricted DEA models, “... it is not so much what ranges of input and output weights are permissible but rather how prior judgements on the relative values of input and output variables can be clarified and incorporated in DEA assessments." (p. 586). Another motivation for using average weights is the possible trade-off between risk and efficiency. On the one hand, an extremely conservative risk attitude is likely to result in inefficiency in the first place; on the other hand, apparently efficient banks may be extremely risky. Therefore we believe that the use of balanced weights across all banks is preferable to extreme weights for individual banks, which can be achieved through weight restrictions based on the average weights.

In terms of the second contribution of the paper, we posit that our method can be used as a regulatory tool to create reference points to complement supervisory benchmarks for risk currently used by regulators, as will be discussed further in Section 5.3 below.

The rest of this paper is structured as follows: In section 2 we provide a brief review of selected literature that links DEA measurement of bank efficiency to bank risk. In section 3 the theoretical DEA models, both without and with weight restrictions, used 
to assess the efficiencies of the banks are defined. Section 4 provides a description of the data, models and variables used for the analysis and section 5 comprises the results. Finally section 6 concludes the paper.

\section{Selected literature review: Bank efficiency measurement and risk}

The recent financial crisis highlighted bank's risks associated with its funding structure, as e.g. over-reliance on wholesale funding exposes a bank to excessive risk if there is a sudden withdrawal of funding in the wholesale funding market, as was the case during the crisis. This is supported by emerging empirical evidence in the wake of the financial crisis. For instance, Bologna (2011) finds evidence from U.S. banks (2007-2009) that banks relying heavily on non-retail deposit or less stable deposit funding are more likely to fail. Vazquez and Federico (2012), considering both European and U.S. banks during 2001-09, also suggest that the strength of a bank's funding liquidity (measured by the proportion of long-term illiquid assets that are funded with liabilities that are either long-term or deemed to be stable (such as core deposits)) prior to the crisis is negatively related to the bank's probability to fail. Consistent with the above European and U.S. findings, Demirguc-Kunt and Huizinga (2009), based on world-wide data, show that a sizeable proportion of banks attract most of their short-term funding from non-retail deposits at a cost of increased bank fragility. The global financial crisis therefore raised questions regarding bank risk management practices and triggered a thorough revision of the regulatory and supervisory frameworks in the new Basel III proposals with stricter regulations on funding and leverage (BIS, 2010).

Besides bank fragility associated with liquidity creation and risks associated with banks' unstable funding structures, the exposure of banks' asset portfolios is also an important concern common to many previous crises in history. It is well known that the burst of the real estate bubble in the United States triggered the recent crisis, which quickly spread to other countries. The cross-country empirical analysis by Claessens et al. (2010) confirms, that countries which had closer links with the U.S. financial system or direct exposure to asset backed securities (i.e. those closer to patient zero) were the first to be affected. Also, those countries displaying features such as rapid credit growth and high leverage, as well as asset price bubbles, were the most severely hurt.

However, banks risks discussed above, which relates specifically to the mixes of funding sources and/or assets, is largely ignored in the bank efficiency literature ${ }^{2}$. Laeven (1990) is amongst the earliest to consider a risk measure in the analysis of bank efficiency and uses excessive loan growth, defined as the growth above the level of loans

\footnotetext{
${ }^{2}$ Note that the selected literature considered here is used to motivate the adoption of weight-restricted data envelopment analysis models for bank efficiency assessment, rather than meant as a meta-analysis of this very large body of literature.
} 
that a bank would have provided if it would have put its inputs to use as efficiently as in a defined base year, as their measure of risk. Hughes et al. (2001) use a best-practice risk-return frontier to measure inefficiency, where expected return is obtained from a managerial utility maximising profit function. Therefore, in their framework, instead of the common considerations of profit maximisation or cost minimisation, a bank is considered efficient if the trade-off between risk and expected return is made with minimum agency cost. More recently, Settlage et al. (2009) propose a DEA model in which banks are assumed to behave as mean-variance utility maximisers. More specifically, their model determines the maximum level of profits given the additional constraint that the observed level of variance of a bank's portfolio (an indicator of risk) cannot be exceeded. This maximum level of expected profit is then compared to the observed level of profits, with equality implying risk-adjusted efficiency. Other studies incorporate risk measures directly into their models to control for risk. For instance, Berg et al. (1992) and Hughes and Mester (1993) included non-performing loans as an input. Altunbas et al. (2001) use equity capital and Pastor and Serrano (2005) incorporate loan loss provisions in their efficiency estimations to control for risk. There are also studies treating risk as an external factor and analysing the effect of risk on efficiency in two-stage DEA or Stochastic Frontier Analysis ${ }^{3}$ models, see for instance Chang (1999), Carvallo and Kasman (2005), Yildirim and Philippatos (2007) and Koutsomanoli-Filippaki and Mamatzakis (2011).

The present work differs from the above studies by proposing a way to incorporate the consideration of risk into the efficiency measurement model without explicitly quantifying the risk beforehand. Based on the lessons learned during the recent financial crisis, we suggest that, besides explicit risk measures such as loan quality (along the lines of what is used in some of the above studies), certain risk as discussed above is implicitly reflected in banks' business models through their reliance on certain inputs and/or outputs. Therefore we, as well as controlling for loan quality and loan loss provision (as explained in section 4), account for this implicit risk element by restricting the weights that are allowed for inputs and outputs in the efficiency measurement. This way, the efficiency model ensures that the risks associated with extreme reliance on certain inputs and/or outputs are properly accounted for in the efficiency assessment, since the banks are not allowed to use correspondingly extreme weights for those variables. Extreme reliance on certain assets or funding sources can arise from both extreme risk preferences and from extreme risk judgements at the practice level. To avoid discouraging heterogeneity in risk preferences regarding the assets or funding portfolios, whilst constraining heterogeneity in risk judgements of particular types of funding or assets, we impose restrictions on weights rather than directly on the assets or funding portfolios.

The research in this paper is also related to another strand of literature discussing the relationship between risk and efficiency. As argued by Berger et al. (1997), the re-

\footnotetext{
${ }^{3}$ Stochastic Frontier Analysis is parametric analysis of efficiency based on a frontier function (such as a production or cost function). It was first proposed by Aigner, Lovell and Schmidt (1977) and Meeusen and van den Broeck (1977) independently.
} 
lationship between efficiency and risk can be in different directions. If bank managers are bad at managing the banks efficiently, the poor management may lead to both low efficiency as well as high levels of problem loans, i.e. higher risk (bad management hypothesis). Alternatively, short-run "inefficiency" of banks devoting resources to loan underwriting and monitoring may lead to less problem loans in the long run, indicating a risk-efficiency trade off (skimping hypothesis). Or the other way around, a bank may take higher risk to pursue short-run efficiency. Similarly, a bank which is currently inefficient may be expected to take higher risk in the near future (also known as the moral hazard hypothesis). Using U.S. evidence, Berger et al. (1997) and Kwan and Eisenbeis (1997) show that poorly performing banks in the U.S. are more vulnerable to risk-taking and increases in problem loans (bad management). However, Altunbas et al. (2007) do not find a positive relationship between inefficiency and bank risk-taking in Europe. Instead, inefficient banks appear to be less risky (skimping). By contrast, using a slightly different sample in Europe, Williams (2004) finds that poorly managed banks tend to make more poor quality loans, consistent with the U.S. evidence. More recently, Fiordelisi et al. (2011) suggest that banks lagging behind in their efficiency levels might expect higher risks in the near future (moral hazard). Wanke et al. (2014) use a sample of Brazilian banks to illustrate that bank management slacks, or input saving or output enhancement potentials, could be good proxies for an eventual financial distress situation. This idea is related to the bad management hypothesis.

The research setting in this paper is quite different from this strand of literature as we are primarily interested in proposing an approach to measuring bank efficiency that more directly incorporates certain risk elements. But the behaviour indicated by the skimping hypothesis makes our approach of measuring bank efficiency (more precisely, the weight-restricted DEA model) relevant and worthwhile: Bank managers may have incentives to take risks in order to boost short-run performance. Since certain risks are reflected in banks' funding and asset portfolio, extreme risk judgements (weights) might have been motivated by short-run profitability. In standard DEA models these extreme judgements would make the corresponding banks appear efficient whereas that is not the case in our proposed weight-restricted models, which more directly account for the associated risks. In the next section we formally define the DEA models used to analyse bank efficiency with and without weight restrictions.

\section{Methodology}

Let $N$ be the set of $n$ observed banks, $j=1, \ldots, n$ described in section 4.1 below. The banks are observed in four different years, $\mathrm{t}=2006, \ldots, 2009$, and within each DEA model a bank is viewed as using $k=1, \ldots, r$ inputs to produce $l=1, \ldots, s$ outputs. The specific variables considered in the two different DEA models (funding-assets and assets-income respectively) are defined in section 4.3. Let $\left(x_{j . t}^{k}\right)$ denote bank $j$ 's consumption of the $k^{\prime}$ th input in year $t$ and $\left(y_{j . t}^{l}\right)$ its production of the $l$ 'th output in year $t$. Thus bank $j$ in year $t$ is described as $\left(\mathbf{x}_{j . t}, \mathbf{y}_{j . t}\right) \in \mathbf{R}_{+}^{r+s}$. 


\subsection{Unrestricted DEA models}

The unrestricted output-oriented DEA efficiency score $e_{j_{0} . t_{0}}$ under constant returns to scale (c.f. Charnes et al., 1978) for bank $j_{0}$ within a given year $t_{0},\left(\mathbf{x}_{j_{0} . t_{0}}, \mathbf{y}_{j_{0} . t_{0}}\right) \in \mathbf{R}_{+}^{r+s}$, but compared to pooled frontier comprising all banks in all years of the study period, is in the multiplier form given by

$$
\begin{aligned}
\left(e_{j_{0} . t_{0}}\right)^{-1}=\quad & \min \sum_{k=1}^{r} v_{j_{0} . t_{0}}^{k} x_{j_{0} . t_{0}}^{k} \\
\text { s.t. } \quad & \sum_{l=1}^{s} u_{j_{0} . t_{0}}^{l} y_{j_{0} . t_{0}}^{l} \geq 1 \\
& \sum_{k=1}^{r} v_{j_{0} . t_{0}}^{k} x_{j . t}^{k}-\sum_{l=1}^{s} u_{j_{0} . t_{0}}^{l} y_{j . t}^{l} \geq 0, j=1, \ldots, n, t=2006, \ldots, 2009 \\
& v_{j_{0} . t_{0}}^{k}, u_{j_{0} . t_{0}}^{l} \geq 0, k=1, \ldots, r, l=1, \ldots, s,
\end{aligned}
$$

where the variables $\mathbf{v}_{j_{0} . t_{0}} \in \mathbf{R}_{+}^{r}$ and $\mathbf{u}_{j_{0} . t_{0}} \in \mathbf{R}_{+}^{s}$ are the weights assigned to the inputs and outputs by the bank under analysis (bank $j_{0}$ ) in the specific year $t_{0}$.

When optimizing the normal unrestricted DEA multiplier model (1) above, the bank under analysis $\left(\mathbf{x}_{j_{0} . t_{0}}, \mathbf{y}_{j_{0} . t_{0}}\right)$ will be assigned the weights that makes it appear as efficient as possible, subject only to the constraints that all weights are non-negative and that no bank $j \in N$ in any year $t$ can have an efficiency score $\frac{\mathbf{v}_{j_{0} \cdot t_{0}} \mathbf{x}_{j . t}}{\mathbf{u}_{j_{0} \cdot t_{0}} \mathbf{y}_{j . t}} \geq 1$ with that set of weights.

Various forms of weight restrictions have been proposed in the literature to prevent the selection of what is deemed inappropriate weights, including assigning weights of zero to inputs and/or outputs that the unit performs relatively poorly on or, in this case, using extreme judgements of the risks associated with certain funding sources or assets. Allen et al. (1997) provide a survey of studies on weight restrictions and value judgements in DEA. Of particular relevance to this paper is Charnes et al. (1990)'s cone ratio approach where relative weights, i.e. ratios of weights, are restricted to having to belong to certain cones typically defined based on external expert opinions and/or a set of model units, thus tightening the efficiency assessment. Similar to that approach we in this study use relative weight restrictions, that is, impose restrictions on ratios of weights. Instead of basing the weight restrictions on expert opinions, or a set of model banks, relative weight restrictions are here defined as a range around the average weight for one variable relative to a range around the average weight for another variable. This is done for pairs of weights corresponding to certain extreme mixes of inputs and/or outputs. This way, the weights for any bank are restricted to only belonging to a certain range on 
one input or output relative to the weight on another input or output; for example, the banks can only be assessed using a certain range of weights assigned to wholesale funding relative to the weight on retail funding. It is interesting to note that, in the setting of cost efficiency of bank branches, Camanho and Dyson (2003) use weight restrictions innovatively to overcome the problem of uncertain input prices to enhance cost efficiency measurement. The application of weight restrictions presented in this study focuses on accounting for banks' extreme risk judgement associated with the value the input and output, thus to improve the practice of bank efficiency measurement. Restrictions on the ratios of weights, as applied here, are the most commonly used form of weight restrictions in the literature. However, other types of weight restrictions could, of course, also have been considered, like restrictions on virtual inputs or outputs, cf. Wong and Beasley (1990). These determine the allowed fraction (or importance) of one input (output), relative to the total value of the inputs (outputs). Thus rather than restricting e.g. the weight on property loans relative to the weight on non-property loans in the asset mix model, they would restrict the importance of property loans in the overall asset portfolio.

In the following subsection we specify how these relative weight restrictions, defined from average weights across the fully-dimensional efficient facets, are incorporated into the previous multiplier DEA model (1).

\subsection{DEA models with weight restrictions}

Let $N^{e}$ be the set of banks that are fully efficient in the unrestricted DEA models above, i.e. with $e_{j 0 . t 0}=1$ in model (1). Thus let $N^{e}=\left\{\left(\mathbf{x}_{j . t}, \mathbf{y}_{j . t}\right) \in N \mid e_{j . t}=1\right\}$. We are now interested in computing the average weights, but since the optimal weights for the efficient banks in $N^{e}$ are generally not unique, we instead calculate the average weights across all the fully-dimensional efficient facets spanned by the efficient banks (see e.g. Olesen and Petersen, 2003). Considering the efficient facets, rather than the efficient banks, ensures that the weights for each are uniquely determined. And only including fully-dimensional facets means excluding facets for which the weights on one or more variables are equal to zero. So these facets will each have a unique set of non-zero weights that are optimal for all of the banks spanning, or belonging to, that facet.

In practice, the facets of the efficient frontier can be identified using the QHull software, which also provides information about which observations span each facet and the corresponding weights. Denote the set of fully-dimensional efficient facets by $F$ and let $v_{h}^{k}$ and $u_{h}^{l}$ denote the input- and output weights respectively, on the $h$ 'th facet. Since we in the empirical application only apply weight restrictions limiting the range of the weight on one input relative to the weight on another input, we in the following only define weight restrictions for pairs of inputs, but note that the approach is easily generalized to weights on pairs of outputs or on an input weight relative to an output weight.

The average weight for an input variable $k$, across the set of fully-dimensional efficient 
facets, is calculated as

$$
\bar{v}^{k}=\sum_{h \in F} v_{h}^{k} /|F|
$$

where $|F|$ denotes the cardinality of $\mathrm{F}$. The corresponding sample standard deviation around the sample mean is denoted by $\sigma_{\bar{v}^{k}}$.

Now we can calculate the ratio of the average weights for two inputs $k^{\prime}$ and $k^{\prime \prime}$ and formulate weight restrictions requiring the ratio of allowable weights for $k^{\prime}$ and $k^{\prime \prime}$ to be within the ratios of the average weight plus/minus 0.5 standard deviations as follows:

$$
W R\left(k^{\prime}, k^{\prime \prime}\right)=\frac{\bar{v}^{k^{\prime}}-0.5 \sigma_{\bar{v}^{k^{\prime}}}}{\bar{v}^{k^{\prime \prime}}+0.5 \sigma_{\bar{v}^{k^{\prime \prime}}}} \leq \frac{v^{k^{\prime}}}{v^{k^{\prime \prime}}} \leq \frac{\bar{v}^{k^{\prime}}+0.5 \sigma_{\bar{v}^{k^{\prime}}}}{\bar{v}^{k^{\prime \prime}}-0.5 \sigma_{\bar{v}^{k^{\prime \prime}}}}
$$

For the pairs of (here) inputs for which relative restrictions are desired, the corresponding ranges of allowable weights are defined from equation (3), linearised, and simply added as constraints to the DEA multiplier model (1). Note that we, in a few cases where an average weight minus 0.5 standard deviations becomes negative, replace the value with a small positive number. Furthermore, while the choice of \pm 0.5 standard deviations as the range for the weight restrictions is quite arbitrary, we have as a robustness check experimented with different widths of these ranges, c.f. section 5.4., and found that the overall results and conclusions in terms of patterns are not sensitive to this choice. Finally, while we here use a simple average of the weights (multipliers) across the facets, one might also consider to use a weighted average where the multipliers for a facet are weighted by, for example, the size of the facet or the number of (inefficient) observations projecting onto that facet.

Adding the weight restrictions means that some previously efficient banks are now deemed inefficient because the weights that made them appear efficient are no longer permissible.

Instead of determining the weight restrictions based on the average weights across the fully-dimensional efficient facets, on might also consider defining the restrictions from the weights for the average observation in the data set (see e.g. Kuosmanen et al., 2010). Therefore we in this paper also consider the results from models where the weight restrictions are based on the optimal weights for the average bank, i.e. the $\mathbf{v}^{*} \in \mathbf{R}_{+}^{r}$ and $\mathbf{u}^{*} \in \mathbf{R}_{+}^{s}$ solving

$$
\begin{array}{ll} 
& \min \sum_{k=1}^{r} v^{k}\left[\sum_{t=2006}^{2009} \sum_{j=1}^{n} x_{j . t}^{k} / 4 n\right] \\
\text { s.t. } & \sum_{l=1}^{s} u^{l}\left[\sum_{t=2006}^{2009} \sum_{j=1}^{n} y_{j . t}^{l} / 4 n\right] \geq 1,
\end{array}
$$




$$
\begin{aligned}
& \sum_{k=1}^{r} v^{k}\left[\sum_{t=2006}^{2009} \sum_{j=1}^{n} x_{j . t}^{k} / 4 n\right]-\sum_{l=1}^{s} u^{l}\left[\sum_{t=2006}^{2009} \sum_{j=1}^{n} y_{j . t}^{l} / 4 n\right] \geq 0, \\
& \sum_{k=1}^{r} v^{k} x_{j . t}^{k}-\sum_{l=1}^{s} u^{l} y_{j . t}^{l} \geq 0, j=1, \ldots, n, t=2006, \ldots, 2009 \\
& v^{k}, u^{l} \geq 0, k=1, \ldots, r, l=1, \ldots, s .
\end{aligned}
$$

Using the average observation does not, in theory, guarantee all non-zero weights nor a unique set of weights, though both are highly likely since the average observation, being located "in the middle of the data set", is likely to project onto a fully-dimensional efficient facet. Note also that if using the average observation to define weight restrictions, those are likely to have a larger impact on the group of observations located furthest away from this point. Whether this is the case here will be investigated empirically in section 5.4 below.

\section{Data}

The data used to analyse the risk and efficiency of the European banks includes annual observations $(2006, \ldots, 2009)$ from 71 European banks head-quartered in 20 different member states. This sample of banks, with total assets of EUR 27,021 billion at the end of 2009, represents approximately $63 \%$ of the total assets of the EU-27 banking system. All data are collected directly from each bank's audited financial reports. All data are adjusted for inflation using the Harmonised Index of Consumer Prices compiled by Eurostat.

\subsection{Sample selection}

The selection of the sample follows the principle used by the 2010 EU-wide stress test exercise conducted by the Committee for European Banking Supervisors (CEBS) ${ }^{4}$ for its selection of the sample banks. The CEBS sample is designed to be representative enough to provide a good proxy of the overall resilience of the EU banking sector. The scope includes the major EU cross-border banking groups and a group of additional, mostly large, credit institutions in Europe. In each EU member state, the sample has been constructed by including banks, in descending order of size, so as to cover at least $50 \%$ of the national banking sector, expressed in terms of total assets. Once the market share, in terms of total assets, reached $50 \%$ no other banks were included from that member state, unless it voluntarily wished to include additional banks. Two special cases are Germany and Spain. In Germany, the public banking sector, dominated by 7 Landesbanken, faced severe financial difficulties during the crisis. Consequently 14 banks, including both the largest commercial banks and the publicly owned Landesbanken, have been included, representing more than $50 \%$ of the market share in the German banking system in terms

\footnotetext{
${ }^{4}$ Detailed information about the EU-wide stress test is available at http://www.cebs.org/EuWideStressTesting.aspx
} 
of total assets. In Spain 27 banks were included, representing around $95 \%$ of the Spanish banking system in terms of total assets, amongst which 25 were domestic savings banks (CAJAs) representing around $40 \%$ of the assets in the Spanish banking system. These savings banks also faced severe financial difficulties during the crisis. As a result the EU-wide stress test includes 91 banks in total.

In this study, for the sake of consistency and comparability, banks are included in descending order of size to cover at least $50 \%$ of the national banking sector in terms of total assets. We divide the banks into two groups, of those that were bailed out by their respective governments during the crisis and those that were not, according to the state aid they received during the crisis: The banks that received substantial government support during the crisis and were required to undergo far-reaching restructuring to return to viability (bailed-out banks), and banks that may have had access to government support through national-level general schemes (such as a central bank liquidity facility or state guarantee) but were not required to undergo restructuring (nonbailed-out banks). During the crisis, the EU member states intervened on a large scale to rescue failing financial institutions. In order to ensure that the rescue measures in each member state could attain the objectives of financial stability and maintenance of credit flows, whilst still ensuring a level playing field between banks located in different member states as well as between banks which received public support and those which did not, avoiding harmful subsidy races, limiting moral hazard and ensuring the competitiveness and efficiency of European banks, the European Commission intervened to control the aid granted by each of the member states. Five successive communications providing guidance on the design and implementation of state aid in favour of banks were issued between October 2008 and July 2009. The guidance relates to two types of aid: 1) General schemes to aid all banks, and 2) Ad hoc interventions in support of a particular bank. Detailed information on the general guidance and on specific cases are available from the European Commission's website and the European Commission's state aid register.

In our sample, there are 23 banks that received significant amounts of aid (in the form of capital injections, toxic asset relief measures and state guarantees) approved by the European Commission on an individual basis (type 2 above). These banks are considered by the national authorities and/or the European Commission as financially distressed banks which require far-reaching restructuring over the next few years to restore viability. Some of these banks were not included in the EU-wide stress test but are included in our study. Moreover, our sample includes 5 Spanish savings banks (which now belong to 3 savings bank groups following mergers and restructuring of the Spanish savings banking industry) which failed the EU wide stress test in 2010. Detailed data for the other 2 savings groups that also failed the stress test were not available. Finally, the Greek bank ATE is included since it also failed the EU wide stress test in 2010. The rest of the banks are considered by the national authorities and/or the European Commission to be internally efficient and sound, but adversely affected by the extreme 
market conditions during the crisis. They still had access to government support through general schemes open to all banks (type 1 above), but these banks were expected to be able to return to viability with the general-scheme support and without far-reaching restructuring. The total number of banks included in our sample is 71, of which 29 are classified as bailed-out, having received significant amounts of aid and/or failed the EU stress test whereas the remaining 42 banks are classified as non-bailed-out, c.f. the last column in Table 1 below.

It is worth noting that the EU banks have been selected on a group-wide basis. This means that subsidiaries and branches of a cross-border operating bank are included as part of its consolidated group in the sample. As such, all EU Member States are covered and the banks in the sample are head-quartered in 20 EU Member States. In the remaining $7 \mathrm{EU}$ member states, more than $50 \%$ of the local market was already covered by foreign banks. The list of banks included in this study, with their market shares (in terms of total assets) in the EU-27 banking system, is shown in the Appendix.

\subsection{Differences between bailed-out and non-bailed-out banks}

The concerns about funding- and asset-portfolio risks emerging from the recent crisis, as discussed in the introduction and literature review, are supported by the data collected for this paper, as evidenced by the results from some preliminary analysis presented in the following.

Table 1 below shows the differences in funding structures and asset portfolios between bailed-out and non-bailed-out banks. In Table 1, wholesale funding includes inter-bank lending, debt securities issued and subordinated debt; total funding includes retail funding (deposit from individuals and firms) and wholesale funding. Property loans include loans to the real estate sector not including residential mortgages. Trading financial assets are assets traded on banks' own accounts; total financial assets include trading and non-trading assets (available-for-sale assets, held-to-maturity assets and other financial assets). Subsection 4.3 below provides further details about the variable definitions.

Table 1 shows the mean values of different types of funding, loans and financial assets of each group. In terms of funding structure (measured by wholesale funding/wholesale and retail funding), the bailed-out banks (B) rely significantly more on wholesale funding than banks that were not bailed out $(\mathrm{NB})^{5}$.

In terms of the loan portfolio (indicated by property loans/property and non-property loans to non-bank customers), group B has a significantly higher proportion of property loans than group NB. In terms of trading assets (measured by the ratio of trading financial assets/trading and non-trading financial assets), the size of the trading portfolio of group B is, on average, (weakly) significantly smaller than that of group NB. It is

\footnotetext{
${ }^{5}$ The comparisons of sample means in both Table 1 and Table 2 are done using t-test, without assuming equal variances (as in some cases the variance in one of the groups is twice as large as that in the other).
} 
Table 1: Mean comparisons of funding structure, and loan and financial asset portfolio between bailed-out (B) and non-bailed-out (NB) banks

\begin{tabular}{|c|c|c|c|c|c|c|c|c|}
\hline & \multicolumn{2}{|c|}{ Year 2006} & \multicolumn{2}{|c|}{ Year 2007} & \multicolumn{2}{|c|}{ Year 2008} & \multicolumn{2}{|c|}{ Year 2009} \\
\hline & B & NB & B & NB & $\mathrm{B}$ & NB & B & NB \\
\hline No. of Obs. & 29 & 42 & 30 & 42 & 29 & 43 & 29 & 42 \\
\hline $\begin{array}{l}\text { Wholesale funding/Total Fund- } \\
\text { ing }(\%)\end{array}$ & 52.9 & 42.2 & 53.4 & 42.9 & 49.7 & 41.1 & 49.0 & 40.9 \\
\hline T-test (HA: Difference $\neq 0$ ) & \multicolumn{2}{|c|}{$2.14(0.0366)$} & \multicolumn{2}{|c|}{$2.16(0.0350)$} & \multicolumn{2}{|c|}{$1.83(0.0726)$} & \multicolumn{2}{|c|}{$1.77(0.0831)$} \\
\hline $\begin{array}{l}\text { Property loans/Total loans to } \\
\text { non-bank customers (\%) }\end{array}$ & 16.9 & 9.6 & 18.1 & 10.1 & 16.6 & 10.5 & 16.2 & 10.2 \\
\hline T-test (HA: Difference $\neq 0$ ) & 2.0 & $.0501)$ & 2.29 & $.0279)$ & 2.50 & $0164)$ & 2.3 & $.0226)$ \\
\hline $\begin{array}{l}\text { Trading financial assets/Total } \\
\text { financial assets (\%) }\end{array}$ & 32.5 & 44.8 & 31.2 & 44.1 & 34.0 & 46.6 & 29.0 & 40.8 \\
\hline T-test (HA: Difference $\neq 0$ ) & -1.7 & $.0833)$ & -1.9 & $.0611)$ & -1.70 & $.0937)$ & -1.7 & $0.0843)$ \\
\hline
\end{tabular}

a. Data sources: Banks' audited financial statements.

b. The sample differs slightly from year to year due to data constraints and restructuring of some banks.

c. T-statistics and p-values from mean comparison tests are reported.

possible that banks in group B are less able to diversify risk with their relatively smaller trading portfolios.

The patterns seen in Table 1 suggest that banks with different funding structures and asset portfolios may exhibit different levels of risk. Using extreme funding and/or asset mixes may expose banks to higher risks, and the potentially inappropriate mixes are in turn revealed by the weights assigned to a bank's inputs and outputs in the efficiency measurement models, where low weights would be put on e.g. an input they use a lot of, thereby implicitly underestimating its cost - including risk. Inspired by the above observations, we incorporate such risks into the measurement of bank efficiency by use of the weight restrictions defined in section 3.2., specifically for the relative weights on pairs of inputs, in accordance with the findings in Table 1.

\subsection{Model specifications and variables}

In the empirical analysis we consider the funding portfolio (mix) and the asset portfolio (mix) separately in two different DEA models, modelling the transformation from funding (and other inputs) to assets and from assets (including loans) to income respectively. The aim is to better understand risks arising from inappropriate funding mixes vis-a-vis asset mixes. When assessing the efficiency related to the funding mix, we adopt an intermediation approach where banks are perceived as entities that transform deposit and funding into loans and financial assets. Under this specification, the input variables include retail funding expenses, wholesale funding expenses, physical capital expenses and personnel expenses. On the output side, we include loans and financial assets. We also include impaired loan on the input side as discussed below. A list of all variables 
used in the funding- and asset-mix models is provided in the appendix.

To analyze the risk and efficiency related to asset mixes (i.e. different types of loans and financial assets), we specify a model where banks are viewed as transforming various loans (including property and non-property loans) and financial assets (trading and non-trading financial assets) into income. We also include impaired loans on the asset side and provision for impaired loan loss on the income side, also discussed below, as a way of directly controlling for risks associated specifically with the quality of the loan portfolio. Under this specification, prices are assumed to be endogenous. In particular, we assume that the pricing of certain loans and assets are, or should be, related to their underlying risks. Therefore higher risk taking should be compensated for by a higher income, in order for a bank to be deemed efficient.

Our approach of applying both a funding mix model and an asset mix model also provides insight into banks' performance both on the operation side and on the profitability side as has been emphasized in earlier studies (e.g. Seiford and Zhu, 1999; Soteriou and Zenios, 1999). The contribution of our study is that we control for the risk arising from the funding mix and the asset mix respectively when assessing the performance related to banks' operation and profitability.

The definition of each of the variables included in the models is as follows: Retail funding refers to deposits received from the retail funding market, i.e. deposits from individuals and firms. Wholesale funding refers to funding obtained from the wholesale funding market, including inter-bank market funding, debt securities issued by the bank, and subordinated debt of the bank. We differentiate retail funding from wholesale funding to explicitly consider the varying reliance on the wholesale funding market by the studied banks evident from Table 1.

All loans are net loans after banks' provisions for impairment losses. Property loans are distinguished from other loans since the decline of the property market during the crisis led to significant losses from bad loans in this part of many banks' loan portfolios. Trading financial assets are debt securities and equity securities acquired principally for the purpose of trading in the near term as well as positive fair values of trading derivatives. These assets are held by the banks for trading on their own account (the so-called proprietary trading). On the one hand, excessive holding of trading assets by banks may expose them to market volatility, especially under extreme market conditions. On the other hand, the trading portfolio may have to be of a relatively substantial size to be able to achieve the effect of risk diversification. During the recent crisis, some distressed banks suffered from high trading losses. Therefore we, in this study, distinguish trading assets from other types of financial assets. Other financial assets, used as one of the asset measures, include available-for-sale financial assets, held-to-maturity financial assets and other financial assets. Available-for-sale financial assets include equity and debt securities which are not held for trading in the near term. They are held for an in- 
definite period of time and may be sold in response to needs for liquidity or in response to changes in market conditions. Held-to-maturity financial assets are non-derivative assets with fixed or determinable payments and fixed maturities and the bank has the intention and ability to hold them until maturity.

The income variable is generated as the sum of net interest income, net commission income, net trading income and all other operating income.

As mentioned previously, to ensure that the risk elements reflected in the banks' funding and investment portfolio model are taken into account when measuring banks' efficiency, we make the above distinctions regarding a bank's funding, loans and financial assets. In addition to accounting for extreme judgements of the risks associated with different funding sources or/and assets, another important aspect that reflects a bank's risk strategy is the quality of the assets. In the literature, there are different approaches for introducing the quality of loans as an element of risk into a DEA model. For instance, Hughes and Mester (1993) add non-performing loans as a quality measure for total outputs taking account of risk. Charnes et al. (1990) instead considers loan loss provision as an additional input together with accumulated loan losses.

In this study, we include impaired loan as an input and provision for impaired loan loss as an output in our asset mix model, and use the impaired loans as an input in our funding mix model. There are several advantages of adopting this approach: Firstly, by introducing impaired loans on the input side, banks with bad management of problem loans who would otherwise achieve higher short term efficiency by accumulating problem loans are appropriately penalised. Secondly, by introducing provision for impaired loan loss on the output side, banks with a prudent perception of the losses from the impaired loans are appropriately rewarded. It is worth noting that the provision for impaired loan loss indicates banks' risk perception, not only based on past loss experience but also based on predictions of future risk conditions. This point is particularly important in the context of the global crisis. The relevant issue is whether banks are allowing adequate losses arising from the impaired loans. As shown in Table 2, in spite of the sharp increase in both impaired loans and provision for loan impairment loss during the crisis, the ratio of loan loss provision over total impaired loans is decreasing for both bailed-out and non-bailed-out banks, i.e. the increase in impaired loans is greater than the increase in loan loss provision. While we can not conclude from Table 2 whether banks are making adequate provision for impairment losses corresponding to the increasing amounts of impaired loans, the mean comparison tests in Table 2 show that non-bailed-out banks have significantly higher loan loss provisions than bailed-out banks given the amount of impaired loans. For the above reasons, we believe it is important to introduce both impaired loans and provision for loan impairment losses into our DEA models. Considering that provision for impaired loan loss directly affects banks' income or profit, and to avoid double counting, we adopt this approach of impaired loans as input and provision for impaired loan loss on the output side in our asset mix model. In the funding mix 
model, we only include impaired loans on the input side to control for loan quality. The detailed definition of impaired loans and provision for impaired loan loss is given below.

Impaired loans are defined under the International Accounting Standard (IAS 39). A financial asset or a group of financial assets is impaired and impairment losses are incurred if, and only if, there is objective evidence of impairment as a result of one or more loss events. Thus, unlike non-performing loans whose definition can be different from bank to bank, the above defined impaired loan gives consistent definition of loan quality across different banks. According to the IAS, if there is objective evidence that an impairment loss on financial assets has occurred, the amount of loss is measured as the difference between the asset's carrying amount and the present value of estimated future cash flows ${ }^{6}$. The carrying amount of the asset is then reduced by the amount of loss (either directly or through use of an allowance account ${ }^{7}$ ). Although the IAS sets certain standards for the estimation of future cash flows to measure impairment loss, this estimation involved in impairment loss allowance/provision of a bank inevitably reflects a bank's value judgement and risk perception regarding how much impairment loss to set aside out of the impaired assets. Although the methodology and assumptions used for estimating future cash flows may be reviewed, there might be a lag in the adjustment in the difference between loss estimates and actual loss experience. Therefore the provision for loan impairment loss can be perceived as a measurement of how much loss a bank sets aside as risk insurance. In other words, given the amount of impaired loan, the provision for the impairment loss should reflect a bank's perception of the cost of the risks associated with the impaired assets.

The above procedure of including impaired loans and loan loss provision resembles the approach applied in Brockett et al. (1997). They also used the provisional loan loss as an output regarding it as "provision for risk insurance", but treated the amount of impairment loss charged for the concerned accounting year as an input. Since the amount of impairment loss charged for the concerned accounting year is based on the provisional loan loss (at the balance sheet date) on the output side, it also reflects banks' risk perception. It runs the risk of penalising banks of charging high impairment loss each year due to prudential perception of risk. However using impaired loan on the input side addresses this problem since, as mentioned above, it is the objective evidence of loan losses without reflecting banks' risk perception.

In addition, considering that the impaired loans are not a real input in a bank's intermediation production plan and that the incorporation of this variable is primarily to control for loan quality of banks, we do not apply weight restrictions relating to this input variable. The weight restrictions are primarily used to adjust bank risk arising from extreme mixes of, or judgements of the risks of, loans and assets instead of the

\footnotetext{
${ }^{6} \mathrm{By}$ definition it is possible for accumulated losses over time to exceed the asset's carrying amount.

${ }^{7}$ Meanwhile, the amount of loss incurred for the concerned accounting year is reflected in the profit or loss.
} 
quality of the loans.

Table 2: Mean comparisons of impaired loans, provision for loan impairment loss and provision for loan impairment loss/impaired loan between bailed-out (B) and non-bailedout banks (NB)

\begin{tabular}{|c|c|c|c|c|c|c|c|}
\hline & \multicolumn{3}{|c|}{ Bailed-out (B) } & \multicolumn{4}{|c|}{ Non-bailed-out (NB) } \\
\hline & Year & Year & Year & Year & Year & Year & Year \\
\hline & 2006 & 2007 & 2009 & 2006 & 2007 & 2008 & 2009 \\
\hline No. of Obs. & 29 & 29 & 29 & 42 & 42 & 43 & 42 \\
\hline \multirow{2}{*}{$\begin{array}{l}\text { Impaired loans (Euro } \mathrm{m} \text { ) } \\
\text { Overall } \\
\text { T-test (HA: Difference } \neq 0 \text { ) }\end{array}$} & 3196.4 & $\begin{array}{ll}3196.6 & 5538.7\end{array}$ & 10266.6 & 3463.9 & 4043.9 & 5270.0 & 8241.6 \\
\hline & \multicolumn{2}{|r|}{5529.5} & $0.13(0.9004)$ & \multicolumn{3}{|c|}{5248.2} & \\
\hline \multirow{2}{*}{$\begin{array}{l}\text { Provision for loan impairment loss } \\
\text { (Euro m) } \\
\text { Overall } \\
\text { T-test (HA: Difference } \neq 0 \text { ) }\end{array}$} & 1711.1 & 1664.32597 .6 & 4596.5 & 2643.5 & 3124.4 & 3915.4 & 5455.4 \\
\hline & \multicolumn{2}{|r|}{2634.0} & $-2.26(0.0249)$ & \multicolumn{3}{|c|}{3785.5} & \\
\hline \multirow{2}{*}{$\begin{array}{l}\text { Provision for loan impairment } \\
\text { loss/impaired loans }(\%) \\
\text { Overall } \\
\text { T-test (HA: Difference } \neq 0)\end{array}$} & 75.7 & 57.5 & 49.4 & 95.5 & 81.4 & 66.1 & 60.6 \\
\hline & \multicolumn{2}{|r|}{64.4} & $-1.89(0$ & \multicolumn{3}{|c|}{75.9} & \\
\hline
\end{tabular}

\section{Results}

In this section, we first present the results of an efficiency analysis using pooled data (across all four years, 2006-2009) with and without weight restrictions. The decreases in the banks' efficiency scores caused by the introduction of weight restrictions are considered to be indicators of the banks' underlying risk, and the average decreases for bailed and non-bailed-out banks are compared. Our pooled analysis show that the imposition of weight restrictions have significantly different impacts on the bailed than on the nonbailed-out banks.

Since one might challenge the appropriateness of using a pooled frontier in the efficiency analysis, especially during such a turbulent time period, where the frontier is likely to be unstable, we next perform similar analysis within each of the four years separately. This serves both as a robustness check for the results from the pooled analysis, but also enables us to investigate whether banks with higher decrease in weight restricted scores (indicating higher risk) before the onset of the crisis (specifically in 2006) are more likely to be the banks ending in more serious trouble during the actual crisis and thus subsequently requiring bail-out. Therefore, a comparison of the decrease from weight restrictions in 2006, between the subsequently bailed and non-bailed banks is of particular interest.

Finally, we identify a set of consistently reasonably efficient banks in the weight restricted models, which we consider to be relevant role model for supervision of bank 
capital requirements.

\subsection{Pooled analysis of efficiency scores with and without weight re- strictions}

Table 3 below presents the average unrestricted DEA scores for the (117) bailed-out and the (169) non-bailed out banks, in both the funding- and the asset-mix model. In the next row are shown the corresponding average scores where the weight restrictions defined in section 3.2 have been applied on all inputs relative to the first input (retail funding in the funding mix model and property loan in the asset mix model), excluding however restrictions on impaired loans, as explained in section 4.3.

We then show the average decrease in the efficiency scores resulting from the application of the weight restrictions defined from the average weights (by design, the weight restricted scores can only decrease compared to the unrestricted scores). Next we compare the decrease in efficiency scores between bailed-out banks and non-bailedout banks, expecting that bailed-out banks (which arguably are more extreme in their risk judgement leading to their known failures) are likely to be more affected by the weight restrictions, due to their extreme choices of portfolio mixes and corresponding risk judgements. We do, however, recognise that some non-bailed-out banks may have been lucky to get away with only receiving general rather than individual aid, but may still be intrinsically unsound. Therefore we may not necessarily observe a distinctive contrast between bailed and non-bailed-out banks in all the results.

Table 3: Unrestricted and weight restricted (WR) efficiency scores (\%) for bailed (B) and non-bailed (NB) banks: Pooled analysis

\begin{tabular}{|c|c|c|c|c|}
\hline & \multicolumn{2}{|c|}{ Funding mix } & \multicolumn{2}{c|}{ Asset mix } \\
\hline & B & NB & B & NB \\
\hline No. of banks & 117 & 169 & 117 & 169 \\
\hline Unrestricted scores & 66.4 & 67.2 & 39.7 & 63.4 \\
\hline WR scores & 61.7 & 62.8 & 31.0 & 59.0 \\
\hline $\begin{array}{c}\text { Decrease in scores } \\
\text { of unrestricted scores) }\end{array}$ & 6.8 & 5.5 & 17.7 & 6.9 \\
\hline $\begin{array}{c}\text { MW test z-statistics } \\
\text { (p-values) }\end{array}$ & $\begin{array}{c}|c| 68 \\
(0.0075)\end{array}$ & $\begin{array}{c}|c| \\
(0.0000)\end{array}$ \\
\hline
\end{tabular}

In Table 3 we see that the average unrestricted efficiency scores for the bailed-out and the non-bailed-out banks are very similar in the funding mix model, whereas the nonbailed-out banks have significantly larger efficiency scores than the bailed-out banks in the asset mix model. This pattern remains when looking at the weight restricted scores. But looking finally at the decrease in efficiency scores resulting from the imposition of weight restrictions, it is interesting to observe that the decrease in scores is largest for 
the bailed-out banks. That this difference between the groups, in terms of the decrease in scores from the weight restrictions, is significant is confirmed by (non-parametric) Mann-Whitney tests, the results of which are shown in the last row of Table 3. So it seems that the bailed-out banks are more affected by the imposition of the weight restrictions limiting their abilities to use extreme weights (risk judgements), than nonbailed-out banks are.

Table 4 below shows the banks with the largest decreases in efficiency scores caused by the introduction of weight restrictions, determined as those banks with decreases above the 50th or 75 th percentile, for both the funding mix model and the asset mix model.

Table 4: Proportion of bailed-out (B) banks amongst the banks with the largest decreases in efficiency scores after weight restrictions: Pooled analysis

\begin{tabular}{|c|c|c|c|c|c|c|c|c|c|}
\hline \multirow[t]{2}{*}{ Year } & \multicolumn{3}{|c|}{$\begin{array}{l}\text { Decrease in scores above } \\
\text { the threshold of } 50 \text { th percentile }\end{array}$} & \multicolumn{3}{|c|}{$\begin{array}{l}\text { Decrease in scores above } \\
\text { the threshold of } 75 \text { th percentile }\end{array}$} & \multicolumn{3}{|c|}{ Total sample } \\
\hline & $\begin{array}{l}\text { No. } \\
\text { of B } \\
\text { banks }\end{array}$ & $\begin{array}{l}\text { No. of B } \\
\text { and NB } \\
\text { banks }\end{array}$ & $\begin{array}{l}\% \text { of } \mathrm{B} \\
\text { banks }\end{array}$ & $\begin{array}{l}\text { No. } \\
\text { of B } \\
\text { banks }\end{array}$ & $\begin{array}{l}\text { No. of B } \\
\text { and NB } \\
\text { banks }\end{array}$ & $\begin{array}{l}\% \text { of } \mathrm{B} \\
\text { banks }\end{array}$ & $\begin{array}{l}\text { No. of } \\
\text { B }\end{array}$ & $\begin{array}{l}\text { No. of B } \\
\text { and NB } \\
\text { banks }\end{array}$ & $\begin{array}{l}\% \text { of } \mathrm{B} \\
\text { banks }\end{array}$ \\
\hline $\begin{array}{l}\text { Funding mix } \\
\text { Asset mix }\end{array}$ & $\begin{array}{l}69 \\
78\end{array}$ & $\begin{array}{l}136 \\
138\end{array}$ & $\begin{array}{l}50.7 \\
56.5\end{array}$ & $\begin{array}{l}30 \\
45\end{array}$ & $\begin{array}{l}63 \\
68\end{array}$ & $\begin{array}{l}47.6 \\
66.2\end{array}$ & $\begin{array}{l}117 \\
117\end{array}$ & $\begin{array}{l}286 \\
286\end{array}$ & $\begin{array}{l}40.9 \\
40.9\end{array}$ \\
\hline
\end{tabular}

From Table 4 we see, that whilst the bailed-out banks constitute around $41 \%$ of the total sample of banks, there are around $50 \%$ bailed banks amongst those with a decrease above the 50th percentile and $48 \%$ bailed banks amongst those with a decrease above the 75 th percentile in the funding mix model. With regard to the asset mix model, we find an even clearer overrepresentation of bailed-out banks amongst the banks experiencing the largest decreases in efficiency scores. As an example to illustrate this, the British bank HBOS, which was later acquired by Lloyds Banking Group, failed disastrously during the crisis $^{8}$. One of the reasons for the failure was that it had very aggressive lending portfolios. However, this bank is considered efficient by the unrestricted asset mix model. But the application of weight restrictions lowered the efficiency scores massively from $100 \%$ to nearly $0 \%$ in 2008 when the crisis hit. Thus besides on average having larger absolute decreases in efficiency scores following the weight restrictions, the bailed-out banks are also overrepresented amongst the banks with the largest decreases. Therefore it is clear that the bailed-out banks are more severely affected by the imposition of weight restrictions limiting their ability to use extreme judgements of risks in their efficiency assessments.

\footnotetext{
${ }^{8}$ See European Commission state aid case No. N428/2009
} 


\subsection{Annual analysis of efficiency scores with and without weight re- strictions}

The pooled analysis above strongly suggests that weight restrictions affect the bailedout banks more than the non-bailed-out banks. It is therefore interesting to see whether this pattern is consistent if the analysis is done within each of the years separately, and furthermore whether there is a relationship between the impact of weight restrictions (indicating extreme and thus risky mixes) before the crisis and the subsequent need for bail-out during the crisis. In 2006, the year just before the hit of the crisis, risky and opportunistic behaviour among banks related to funding and asset exposure is expected to be at a relatively high level. In 2007, the situation is perhaps less clear-cut and it is difficult to predict how different banks' behaviour is likely to be: some banks may still be pursuing highly risky behaviour although the crisis started to hit a small number of banks such as Northern Rock. It is, however, also possible that certain banks may have started to react to changing market conditions in 2007. The bankruptcy of Lehman Brothers in September 2008 which then hit many other banks in the global financial market perhaps symbolise the height of the crisis. In 2009, more European banks required extensive government aid. Therefore, in 2008 and 2009 one could reasonably expect that the crisis would have hit all banks, resulting in less dissimilar and extreme behaviour amongst the banks as a whole. This would perhaps imply less distinctive impact between bailed and non-bailed-out banks arising from weight restrictions. To understand this, we present the result of annual analysis using weight restrictions to see how the impact of weight restrictions differ between bailed and non-bailed-out banks within each of the years 2006-2009.

Unlike pooled analysis that uses one common frontier, the annual analysis uses a separate frontier in each year, which take into consideration the changes in the production possibilities for the financial markets the banks operate in, from 2006 and through the crisis period 2008-2009. This also means that in the annual analysis, we use a different set of weight restrictions in each year. 
Table 5: Unrestricted and weight restricted (WR) efficiency scores (\%) for bailed (B) and non-bailed (NB) banks: Annual analysis

\begin{tabular}{|c|c|c|c|c|c|c|c|c|}
\hline & \multicolumn{8}{|c|}{ Funding mix } \\
\hline & \multicolumn{2}{|c|}{2006} & \multicolumn{2}{|c|}{2007} & \multicolumn{2}{|c|}{2008} & \multicolumn{2}{|c|}{2009} \\
\hline & B & NB & B & NB & B & NB & B & NB \\
\hline Unrestricted scores & 86.2 & 87.1 & 76.2 & 83.5 & 84.8 & 86.0 & 78.4 & 74.4 \\
\hline $\begin{array}{l}\text { MW test z-statistics } \\
\text { (p-values) }\end{array}$ & \multicolumn{2}{|c|}{$\begin{array}{c}-0.44 \\
(0.6581)\end{array}$} & \multicolumn{2}{|c|}{$\begin{array}{c}-1.54 \\
(0.1233)\end{array}$} & \multicolumn{2}{|c|}{$\begin{array}{c}0.27 \\
(0.7854)\end{array}$} & \multicolumn{2}{|c|}{$\begin{array}{c}1.26 \\
(0.2036)\end{array}$} \\
\hline WR scores & 73.3 & 83.6 & 70.3 & 75.5 & 78.8 & 82.5 & 72.7 & 69.9 \\
\hline $\begin{array}{c}\text { MW test z-statistics } \\
\text { (p-values) }\end{array}$ & \multicolumn{2}{|c|}{$\begin{array}{c}-2.36 \\
(0.0182)\end{array}$} & \multicolumn{2}{|c|}{$\begin{array}{c}-1.28 \\
(0.2024)\end{array}$} & \multicolumn{2}{|c|}{$\begin{array}{c}-0.62 \\
(0.5379)\end{array}$} & \multicolumn{2}{|c|}{$\begin{array}{c}0.84 \\
(0.3992)\end{array}$} \\
\hline $\begin{array}{c}\text { Decrease in scores } \\
\text { (\% of unrestricted scores) }\end{array}$ & 15.8 & 4.0 & 9.7 & 9.6 & 7.1 & 4.2 & 7.6 & 5.6 \\
\hline \multirow[t]{4}{*}{$\begin{array}{c}\text { MW test z-statistics } \\
(\mathrm{p} \text {-values })\end{array}$} & \multicolumn{2}{|c|}{$\begin{array}{c}4.48 \\
(0.0000) \\
\end{array}$} & \multicolumn{2}{|c|}{$\begin{array}{c}-0.16 \\
(0.8723)\end{array}$} & \multicolumn{2}{|c|}{$\begin{array}{c}0.96 \\
(0.3363)\end{array}$} & \multicolumn{2}{|c|}{$\begin{array}{c}0.77 \\
(0.4429) \\
\end{array}$} \\
\hline & \multicolumn{8}{|c|}{ Asset mix } \\
\hline & \multicolumn{2}{|c|}{2006} & \multicolumn{2}{|c|}{2007} & \multicolumn{2}{|c|}{2008} & \multicolumn{2}{|c|}{2009} \\
\hline & $\mathrm{B}$ & NB & $\mathrm{B}$ & NB & B & $\mathrm{NB}$ & $\mathrm{B}$ & NB \\
\hline Unrestricted scores & 59.0 & 86.1 & 57.6 & 82.2 & 40.4 & 74.1 & 50.2 & 79.5 \\
\hline $\begin{array}{l}\text { MW test z-statistics } \\
\text { (p-values) }\end{array}$ & \multicolumn{2}{|c|}{$\begin{array}{c}-3.75 \\
(0.0002)\end{array}$} & \multicolumn{2}{|c|}{$\begin{array}{c}-3.14 \\
(0.0017)\end{array}$} & \multicolumn{2}{|c|}{$\begin{array}{c}-4.26 \\
(0.0000)\end{array}$} & \multicolumn{2}{|c|}{$\begin{array}{c}-4.31 \\
(0.0000)\end{array}$} \\
\hline WR scores & 44.7 & 78.9 & 40.5 & 74.7 & 17.6 & 49.9 & 39.7 & 72.3 \\
\hline $\begin{array}{c}\text { MW test z-statistics } \\
\text { (p-values) }\end{array}$ & \multicolumn{2}{|c|}{$\begin{array}{c}-4.95 \\
(0.0000)\end{array}$} & \multicolumn{2}{|c|}{$\begin{array}{c}-5.12 \\
(0.0000)\end{array}$} & \multicolumn{2}{|c|}{$\begin{array}{c}-5.25 \\
(0.0000)\end{array}$} & \multicolumn{2}{|c|}{$\begin{array}{c}-5.02 \\
(0.0000)\end{array}$} \\
\hline $\begin{array}{c}\text { Decrease in scores } \\
(\% \text { of unrestricted scores })\end{array}$ & 21.9 & 8.4 & 25.0 & 9.4 & 43.5 & 31.7 & 18.9 & 8.8 \\
\hline $\begin{array}{l}\text { MW test z-statistics } \\
\text { (p-values })\end{array}$ & $\begin{array}{r}4 . \\
(0.0 \\
\end{array}$ & $900)$ & $\begin{array}{r}3 \\
(0.0 \\
\end{array}$ & 33 & $(0.1)$ & $\begin{array}{l}6 \\
92) \\
\end{array}$ & $(0.0$ & 25 \\
\hline
\end{tabular}

Table 6: Proportion of bailed-out (B) banks amongst banks with the largest decreases in efficiency scores after weight restrictions: Annual Analysis

\begin{tabular}{|c|c|c|c|c|c|c|c|c|c|}
\hline \multirow[t]{2}{*}{ Year } & \multicolumn{3}{|c|}{$\begin{array}{l}\text { Decrease in scores above } \\
\text { the threshold of } 50 \text { th percentile }\end{array}$} & \multicolumn{3}{|c|}{$\begin{array}{l}\text { Decrease in scores above } \\
\text { the threshold of } 75 \text { th percentile }\end{array}$} & \multicolumn{3}{|c|}{ Total sample } \\
\hline & $\begin{array}{l}\text { No. } \\
\text { of B } \\
\text { banks }\end{array}$ & $\begin{array}{l}\text { No. of B } \\
\text { and NB } \\
\text { banks }\end{array}$ & $\begin{array}{l}\% \text { of } \mathrm{B} \\
\text { banks }\end{array}$ & $\begin{array}{l}\text { No. } \\
\text { of B } \\
\text { banks }\end{array}$ & $\begin{array}{l}\text { No. of B } \\
\text { and NB } \\
\text { banks }\end{array}$ & $\begin{array}{l}\% \text { of } \mathrm{B} \\
\text { banks }\end{array}$ & $\begin{array}{l}\text { No. of } \\
\text { B }\end{array}$ & $\begin{array}{l}\text { No. of B } \\
\text { and NB } \\
\text { banks }\end{array}$ & $\begin{array}{l}\% \text { of } \mathrm{B} \\
\text { banks }\end{array}$ \\
\hline & \multicolumn{9}{|c|}{ Funding mix model } \\
\hline 2006 & 23 & 36 & 63.9 & 13 & 17 & 76.5 & 29 & 71 & 40.8 \\
\hline 2007 & 14 & 35 & 40.0 & 6 & 17 & 35.3 & 30 & 72 & 41.7 \\
\hline 2008 & 15 & 36 & 41.7 & 11 & 17 & 64.7 & 29 & 72 & 40.3 \\
\hline \multirow[t]{2}{*}{2009} & 16 & 36 & 44.4 & 10 & 17 & 58.8 & 29 & 71 & 40.8 \\
\hline & \multicolumn{9}{|c|}{ Asset mix model } \\
\hline 2006 & 23 & 37 & 62.2 & 10 & 15 & 66.7 & 29 & 71 & 40.8 \\
\hline 2007 & 20 & 37 & 54.1 & 13 & 17 & 76.5 & 30 & 72 & 41.7 \\
\hline 2008 & 20 & 36 & 55.6 & 9 & 18 & 50.0 & 29 & 72 & 40.3 \\
\hline 2009 & 16 & 35 & 45.7 & 13 & 18 & 72.2 & 29 & 71 & 40.8 \\
\hline
\end{tabular}


The results in Table 5 strongly suggest that in 2006, the drop in weight restricted scores is significantly larger for bailed-out than non-bailed-out banks. This implies that banks with large decreases in weight restricted scores in the year prior to the crisis are more likely to be those which ended up in serious trouble and needed ad hoc government aid during the crisis years. Results from Table 6 confirms that in 2006, among the banks with the largest drops in weight restricted scores (above 50th and 75th percentile), the bailed-out banks are overrepresented compared to the sample distribution. However, and perhaps not surprisingly, the difference between non-bailed-out and bailed-out banks from imposing weight restrictions is not so clear after 2006. As mentioned earlier, this is possibly due to banks becoming less dissimilar or extreme once the crisis hit the whole market where banks are interconnected. Therefore weight restrictions are perhaps more important for periods during which extreme behaviour among some banks is likely.

It is worth noting that in the asset mix model, non-bailed-out banks are significantly more efficient than bailed out banks in each year even without any weight restrictions. This may be due to the design of our asset mix model where (as mentioned earlier) asset price is endogenous and higher risk taking should be compensated for by a higher income, in order for a bank to be deemed efficient. But even in this model, the results in Table 5 and 6 show that weight restrictions still has a larger impact on bailed-out than on non-bailed-out banks.

\subsection{Identifying model banks using weight restricted models}

\subsubsection{Motivation}

Firstly we motivate the exercise of identifying model banks before explaining how our suggested approach contributes in this respect.

The Financial Services Authority ${ }^{9}$, the financial regulator of the UK, conducted socalled hypothetical portfolio exercises in 2007, 2009 and 2011. These experimental exercises take a set of common portfolios and ask how much capital banks' internal models would set against them. The results from these exercises show large differences between banks regarding their judgement of the probabilities of default of the three asset portfolios and associated risk weights. The estimated capital requirements for the most prudent banks were well over three times as high as those of the most aggressive banks for the same portfolios of exposures ${ }^{10}$. Similar tests have also been conducted by the Basel Committee focusing on international banks' trading books (BIS, 2013) and show large variations between banks regarding their judgement of risk weights of various

\footnotetext{
${ }^{9}$ FSA has now become two authorities: The Financial Conduct Authority can be found at www.fca.org.uk and the Prudential Regulation Authority at www.bankofengland.co.uk.

${ }^{10}$ Regarding detailed methods and results of the policy experiments, see FSA (2007) (2010); financial stability report by bank of England 2012, chart 3.18 and 3.19, Bank of England (2012); and the speech by Andrew Haldane, the Executive Director of Financial Stability at Bank of England, Haldane (2013).
} 
classes of assets. Since the hypothetical portfolio is the same for all participating banks, the heterogeneity is not due to differences in underlying (actual) risk which would have been indicated by different mixes of assets given the risk judgement of various types of assets in the portfolio. The heterogeneity is judgement-based arising from different bank practices in both experiments. To further explain the heterogeneity, BIS (2013) shows various sources of differences in practice including for instance, differences in banks' modelling choices (data, methodology, definition of default, adjustment for cyclical effects etc), differences in interpretation of regulatory frameworks, or discretion permitted under the regulatory capital framework etc. This kind of heterogeneity is undesirable if it produces material differences that undermine risk regulation and supervision of banks. One policy option, mentioned in BIS (2013), is to determine additional supervisory benchmarks for the risk parameters used to assess capital ratios and risk weighted assets (the inferred denominator of regulatory capital ratios). These benchmarks might include representative probabilities of default (PD) estimates for particular rating grades or for other indicators of credit quality, representative loss given default (LGD) estimates for various types of exposures, etc.

It is in the determination of these additional supervisory benchmarks that our suggested approach can potentially make an additional contribution. The weights inferred from each bank's input-output portfolio reflect the bank's optimal judgement (in terms of maximizing efficiency) of the risk-adjusted prices of the funding/asset portfolio, that is the risk associated with each variable relative to its cost/return. Since the 'true' risk levels are unknown, allowing only a range of (relative) weights around the average weights means harmonising the heterogeneous risk judgements. Those banks that remain efficient after the imposition of weight restrictions can then be selected as model banks. After selecting model banks, we suggest that the internal estimates (such as PD, LGD etc.) of these model banks, as estimated by the banks themselves using their internal models and data sets, can be used as reference points to constrain the discretion in the choice of risk estimates. This will then constrain the discretion in the capital ratios derived from these risk estimates, thus improving the effectiveness of the regulatory capital benchmarks. Using these constrained risk estimates, banks will have to provide a strong capital base if they choose an exposure that has high underlying risk based on the reference risk estimates.

\subsubsection{Results on model banks}

Having applied weight restrictions to harmonise banks' risk judgement, we now select a set of model banks who consistently, that is across all four years of the study, are amongst the most efficient banks. Applying a threshold of 50th percentile (i.e. banks with restricted scores over the 50th percentile consistently for all four years) using the pooled analysis, results in identifying 3 bailed-out and 9 non-bailed-out banks from the funding mix model (see appendix) and 1 bailed-out and 17 non-bailed-out banks from the asset mix model (see appendix). If we combine the two models, only four banks, that 
are all non-bailed-out, are consistently amongst the best performers in both models, and thus constitute a sensible set of potential reference (or model) banks. These four banks are: BNP, DEUTSCHE, HSBC and OP. It is worth noting that the results demonstrate that it is important to assess both the funding and asset model under our approach when evaluating a bank's efficiency. To illustrate this using an example: Northern Rock (NR) which failed badly during the crisis partly due to its risky funding model (heavily reliant on wholesale funding ${ }^{11}$ ) has its weight restricted efficiency score in the asset mix model at around $100 \%$ but its weight restricted scores in the funding mix model are very low and at their lowest in 2007 (it was hit by the crisis during September 2007) and 2008 at around $5 \%$. This is not to claim that the case of Northern Rock was solely a problem of over-reliance on wholesale funding, nor do we claim that the problem of other major banks in Europe is solely due to over-reliance on property loans. It is inevitable that a problem on the liability side will eventually be reflected on the asset side and vice versa due to the nature of banking activities which include transforming illiquid assets into liquid liabilities. No implication is meant to be drawn from the model or results regarding whether unbalanced funding or assets is more fundamental to the failure of certain banks. Whereas we here analyse the funding mix and the assets mix in two separate models, which allows us to understand how unbalanced funding and assets each contribute to the inefficiency estimated with weight restrictions, an interesting idea for future research could be to consider both mixes together, for example using a two-stage model along the lines of Seiford and Zhu (1999), where in our case the first stage would consider the transformation of funding into assets, and the next the transformation of those assets into income.

Using annual analysis, we identify 1 bailed-out and 9 non-bailed-out banks from the funding mix model and 1 bailed-out and 19 non-bailed-out banks from the asset mix model. If we combine the two models, we identify 5 model banks: BCEE, DEUTSCHE, HSBC, OP and UBI. The two sets of models banks identified by the pooled and by the annual analysis respectively are largely consistent with each other except BCEE, BNP and UBI which are borderline cases in each analysis ${ }^{12}$.

As discussed above, together with regulatory capital ratios, there is the need of supervisory benchmarks to constrain the choice of risk estimates which are used to define and calculate capital ratios. This is to constrain the discretion in the derivation of regulatory capital ratios thus improving the effectiveness of these regulatory capital benchmarks. Once model banks are identified, we propose that the internal risk estimates of the model banks selected by our weight-restricted DEA models can be used as reference points to determine the additional supervisory benchmarks for various risk estimates which are used to define regulatory capital ratios. For instance, in choosing estimates for the PD

\footnotetext{
${ }^{11}$ see European Commission State aid case no. C 14/2008.

${ }^{12}$ To save space, we in the appendix only show the banks selected by the funding and the asset mix model in the pooled analysis. The full set of results regarding all efficiency scores in all models are available upon request.
} 
per rating grade, which gives the average percentage of obligors that default in this rating grade in the course of one year, banks' estimates can differ depending on the choice of their internal estimation models and data. What we are proposing is that, among other regulatory tools, the model banks selected by our weight restricted DEA models can be used as reference points and their internal estimates can be referred to if regulators need to benchmark such kind of risk estimates ${ }^{13}$.

\subsection{Weight restrictions based on the average observation}

As a robustness check we have also repeated all the previous analysis using weight restrictions based on the weights from the average observation (eq. 4), rather than from the average of the weights (across the facets). Table 7 and 8 show the differences between the restricted and unrestricted efficiency scores in the pooled and annual analysis respectively.

Table 7: Unrestricted and weight restricted (WR) efficiency scores (\%) for bailed (B) and non-bailed (NB) banks (based on average observation): Pooled analysis

\begin{tabular}{|c|c|c|c|c|}
\hline & \multicolumn{2}{|c|}{ Funding mix } & \multicolumn{2}{c|}{ Asset mix } \\
\hline & $\mathrm{B}$ & $\mathrm{NB}$ & $\mathrm{B}$ & $\mathrm{NB}$ \\
\hline No. of banks & 117 & 169 & 117 & 169 \\
\hline Unrestricted scores & 66.4 & 67.2 & 39.7 & 63.4 \\
\hline WR scores & 54.1 & 57.7 & 32.9 & 57.8 \\
\hline $\begin{array}{c}\text { Decrease in scores } \\
\text { (\% unrestricted scores) }\end{array}$ & 17.8 & 12.9 & 11.7 & 7.5 \\
\hline MW test z-statistics & \multicolumn{2}{|c|}{3.48} & \multicolumn{2}{|c|}{2.45} \\
(p-values) & $(0.0005)$ & \multicolumn{3}{c|}{$(0.0142)$} \\
\hline
\end{tabular}

\footnotetext{
${ }^{13}$ It is important to note that we are not proposing to, for instance, replace the capital regulation benchmark proposed by the Basel committee, or to use model banks as a set target for other banks. Instead we are proposing to use our method to identify references for additional supervisory purposes for e.g. capital regulation. The motivation is to reduce the discretion among banks in terms of appropriate risk weights they can apply to different assets, resulting in a more effective use of capital ratio regulation.
} 
Table 8: Unrestricted and weight restricted (WR) efficiency scores (\%) for bailed (B) and non-bailed (NB) banks (based on average observation): Annual analysis

\begin{tabular}{|c|c|c|c|c|c|c|c|c|}
\hline & \multicolumn{8}{|c|}{ Funding mix } \\
\hline & \multicolumn{2}{|c|}{2006} & \multicolumn{2}{|c|}{2007} & \multicolumn{2}{|c|}{2008} & \multicolumn{2}{|c|}{2009} \\
\hline & B & NB & B & NB & B & NB & B & NB \\
\hline Unrestricted scores & 86.3 & 87.1 & 76.2 & 83.5 & 84.8 & 86.0 & 78.5 & 74.4 \\
\hline $\begin{array}{l}\text { MW test z-statistics } \\
\text { (p-values) }\end{array}$ & \multicolumn{2}{|c|}{$\begin{array}{c}-0.44 \\
(0.6581)\end{array}$} & \multicolumn{2}{|c|}{$\begin{array}{c}-1.54 \\
(0.1233)\end{array}$} & \multicolumn{2}{|c|}{$\begin{array}{c}0.27 \\
(0.7854)\end{array}$} & \multicolumn{2}{|c|}{$\begin{array}{c}1.26 \\
(0.2036)\end{array}$} \\
\hline WR scores & 71.6 & 78.8 & 74.9 & 81.9 & 82.6 & 85.3 & 75.5 & 72.4 \\
\hline $\begin{array}{c}\text { MW test z-statistics } \\
\text { (p-values) }\end{array}$ & \multicolumn{2}{|c|}{$\begin{array}{c}-1.76 \\
(0.0781)\end{array}$} & \multicolumn{2}{|c|}{$\begin{array}{c}-1.51 \\
(0.1319)\end{array}$} & \multicolumn{2}{|c|}{$\begin{array}{c}-0.18 \\
(0.8578)\end{array}$} & \multicolumn{2}{|c|}{$\begin{array}{c}1.08 \\
(0.2804)\end{array}$} \\
\hline $\begin{array}{c}\text { Decrease in scores } \\
\text { (\% of unrestricted scores) }\end{array}$ & 17.8 & 9.5 & 3.1 & 1.7 & 2.5 & 0.9 & 3.8 & 2.5 \\
\hline \multirow[t]{4}{*}{$\begin{array}{l}\text { MW test z-statistics } \\
(\mathrm{p} \text {-values })\end{array}$} & \multicolumn{2}{|c|}{$\begin{array}{c}2.72 \\
(0.0065) \\
\end{array}$} & \multicolumn{2}{|c|}{$\begin{array}{c}1.68 \\
(0.0935) \\
\end{array}$} & \multicolumn{2}{|c|}{$\begin{array}{c}1.09 \\
(0.2728)\end{array}$} & \multicolumn{2}{|c|}{$\begin{array}{c}0.74 \\
(0.4590) \\
\end{array}$} \\
\hline & \multicolumn{8}{|c|}{ Asset mix } \\
\hline & \multicolumn{2}{|c|}{2006} & \multicolumn{2}{|c|}{2007} & \multicolumn{2}{|c|}{2008} & \multicolumn{2}{|c|}{2009} \\
\hline & $\mathrm{B}$ & $\mathrm{NB}$ & $\mathrm{B}$ & NB & $\mathrm{B}$ & $\mathrm{NB}$ & B & $\mathrm{NB}$ \\
\hline Unrestricted scores & 59.0 & 86.1 & 57.6 & 82.2 & 40.4 & 74.1 & 50.2 & 79.5 \\
\hline $\begin{array}{c}\text { MW test z-statistics } \\
\text { (p-values) }\end{array}$ & \multicolumn{2}{|c|}{$\begin{array}{c}-3.75 \\
(0.0002)\end{array}$} & \multicolumn{2}{|c|}{$\begin{array}{c}-3.14 \\
(0.0017)\end{array}$} & \multicolumn{2}{|c|}{$\begin{array}{c}-4.26 \\
(0.0000)\end{array}$} & \multicolumn{2}{|c|}{$\begin{array}{c}-4.31 \\
(0.0000)\end{array}$} \\
\hline WR scores & 45.9 & 67.5 & 43.2 & 59.1 & 26.2 & 47.6 & 39.3 & 63.0 \\
\hline $\begin{array}{c}\text { MW test z-statistics } \\
\text { (p-values) }\end{array}$ & \multicolumn{2}{|c|}{$\begin{array}{c}-3.35 \\
(0.0008)\end{array}$} & \multicolumn{2}{|c|}{$\begin{array}{c}-2.99 \\
(0.0028)\end{array}$} & \multicolumn{2}{|c|}{$\begin{array}{c}-4.18 \\
(0.0000)\end{array}$} & \multicolumn{2}{|c|}{$\begin{array}{c}-4.51 \\
(0.0000)\end{array}$} \\
\hline $\begin{array}{c}\text { Decrease in scores } \\
\text { (\% of unrestricted scores) }\end{array}$ & 20.4 & 21.5 & 20.8 & 27.2 & 31.1 & 34.6 & 19.2 & 20.3 \\
\hline $\begin{array}{l}\text { MW test z-statistics } \\
\text { (p-values) }\end{array}$ & \multicolumn{2}{|c|}{$\begin{array}{c}-0.188 \\
(0.8513)\end{array}$} & \multicolumn{2}{|c|}{$\begin{array}{c}-1.13 \\
(0.2575)\end{array}$} & \multicolumn{2}{|c|}{$\begin{array}{l}-0.735 \\
(0.4624)\end{array}$} & \multicolumn{2}{|c|}{$\begin{array}{c}-0.222 \\
(0.8240)\end{array}$} \\
\hline
\end{tabular}

It is evident from Table 7 that the pattern regarding the drop in efficiency scores after weight restrictions is consistent with what we observe under the approach of using weight restrictions defined from the average across the efficient facets in the pooled analysis: The decrease in efficiency scores is significantly higher for the bailed-out banks than for the non-bailed-out banks in the pooled analysis.

In Table 8, here annual analyses are performed, we see that year 2006 again witnesses a significantly larger decrease in efficiency scores after weight restrictions amongst bailed than non-bailed-out banks in the funding mix model. While this pattern is clear in the funding mix model under both approaches, it is not so clear in the asset mix model. In the asset mix model we do not find a clear pattern in terms of decrease in efficiency scores after weight restrictions among bailed-out and non-bailed-out banks in any year. As mentioned earlier, our asset mix model by design has to some extent accounted for risk even without weight restrictions (as higher risk must be compensated for higher income to achieve efficiency). This is demonstrated by the significant difference in efficiency scores between bailed-out and non-bailed-out banks without any weight restrictions in Table 8 (second half). By using weights of the average observation as restrictions, we 
can not find that efficiency scores of bailed-out banks drop more than non-bailed-out banks after weight restrictions.

Table 9: Proportion of bailed-out (B) banks amongst banks with the largest decreases in efficiency scores after weight restrictions (based on average observation): Pooled analysis

\begin{tabular}{|c|c|c|c|c|c|c|c|c|c|}
\hline \multirow[t]{2}{*}{ Year } & \multicolumn{3}{|c|}{$\begin{array}{l}\text { Decrease in scores above } \\
\text { the threshold of } 50 \text { th percentile }\end{array}$} & \multicolumn{3}{|c|}{$\begin{array}{l}\text { Decrease in scores above } \\
\text { the threshold of } 75 \text { th percentile }\end{array}$} & \multicolumn{3}{|c|}{ Total sample } \\
\hline & $\begin{array}{l}\text { No. } \\
\text { of B } \\
\text { banks }\end{array}$ & $\begin{array}{l}\text { No. of B } \\
\text { and NB } \\
\text { banks }\end{array}$ & $\begin{array}{l}\% \text { of } \mathrm{B} \\
\text { banks }\end{array}$ & $\begin{array}{l}\text { No. } \\
\text { of B } \\
\text { banks }\end{array}$ & $\begin{array}{l}\text { No. of B } \\
\text { and NB } \\
\text { banks }\end{array}$ & $\begin{array}{l}\% \text { of } \mathrm{B} \\
\text { banks }\end{array}$ & $\begin{array}{l}\text { No. of } \\
\text { B }\end{array}$ & $\begin{array}{l}\text { No. of B } \\
\text { and NB } \\
\text { banks }\end{array}$ & $\begin{array}{l}\% \text { of } \mathrm{B} \\
\text { banks }\end{array}$ \\
\hline $\begin{array}{l}\text { Funding mix } \\
\text { Asset mix }\end{array}$ & $\begin{array}{l}71 \\
62\end{array}$ & $\begin{array}{l}133 \\
137\end{array}$ & $\begin{array}{l}53.4 \\
45.3\end{array}$ & $\begin{array}{l}40 \\
32\end{array}$ & $\begin{array}{l}69 \\
67\end{array}$ & $\begin{array}{l}58.0 \\
47.8\end{array}$ & $\begin{array}{l}117 \\
117\end{array}$ & $\begin{array}{l}286 \\
286\end{array}$ & $\begin{array}{l}40.9 \\
40.9\end{array}$ \\
\hline
\end{tabular}

Table 10: Proportion of bailed-out (B) banks amongst banks with the largest decreases in efficiency scores after weight restrictions (base on average observation): Annual analysis

\begin{tabular}{|c|c|c|c|c|c|c|c|c|c|}
\hline \multirow[t]{2}{*}{ Year } & \multicolumn{3}{|c|}{$\begin{array}{l}\text { Decrease in scores above } \\
\text { the threshold of } 50 \text { th percentile }\end{array}$} & \multicolumn{3}{|c|}{$\begin{array}{c}\text { Decrease in scores above } \\
\text { the threshold of } 75 \text { th percentile }\end{array}$} & \multicolumn{3}{|c|}{ Total sample } \\
\hline & $\begin{array}{l}\text { No. } \\
\text { of B } \\
\text { banks }\end{array}$ & $\begin{array}{l}\text { No. of B } \\
\text { and NB } \\
\text { banks }\end{array}$ & $\begin{array}{l}\% \text { of } \mathrm{B} \\
\text { banks }\end{array}$ & $\begin{array}{l}\text { No. } \\
\text { of B } \\
\text { banks }\end{array}$ & $\begin{array}{l}\text { No. of B } \\
\text { and NB } \\
\text { banks }\end{array}$ & $\begin{array}{l}\% \text { of } \mathrm{B} \\
\text { banks }\end{array}$ & $\begin{array}{l}\text { No. of } \\
\text { B }\end{array}$ & $\begin{array}{l}\text { No. of B } \\
\text { and NB } \\
\text { banks }\end{array}$ & $\begin{array}{l}\% \text { of } \mathrm{B} \\
\text { banks }\end{array}$ \\
\hline & \multicolumn{9}{|c|}{ Funding mix model } \\
\hline 2006 & 24 & 54 & 44.4 & 13 & 18 & 72.2 & 29 & 71 & 40.8 \\
\hline 2007 & 19 & 38 & 50.0 & 11 & 17 & 64.7 & 30 & 72 & 41.7 \\
\hline 2008 & 14 & 36 & 38.9 & 12 & 18 & 66.7 & 29 & 72 & 40.3 \\
\hline \multirow[t]{2}{*}{2009} & 14 & 35 & 40.0 & 11 & 17 & 64.7 & 29 & 71 & 40.8 \\
\hline & \multicolumn{9}{|c|}{ Asset mix model } \\
\hline 2006 & 13 & 35 & 37.1 & 6 & 17 & 35.3 & 29 & 71 & 40.8 \\
\hline 2007 & 13 & 36 & 36.1 & 6 & 18 & 33.3 & 30 & 72 & 41.7 \\
\hline 2008 & 13 & 36 & 36.1 & 6 & 18 & 33.3 & 29 & 72 & 40.3 \\
\hline 2009 & 14 & 35 & 40.0 & 7 & 17 & 41.2 & 29 & 71 & 40.8 \\
\hline
\end{tabular}

In Table 9 and Table 10, which compares the sample proportion of bailed-out banks to the proportion of non-bailed-out banks among those with the largest decrease in efficiency scores (most affected by weight restrictions) in the pooled and in the annual analysis respectively analysis, the results are again consistent with the approach of weight restrictions across efficient facets: Under the average unit approach we again find that the proportion of bailed-out banks amongst those banks most affected by weight restrictions is higher than the sample proportion.

The list of model banks resulting from applying the average unit approach is largely similar to that from the previous approach, both in the funding-mix model and the assetmix model. Using poled analysis, the set of reference banks selected using this approach 
is exactly the same as the one reported with the facet approach, i.e. BNP, DEUTSCHE, HSBC and OP; using annual analyses we identify the following model banks based on average observation weight restrictions: BNP, DEUTSCHE, HSBC, OP and SHB. Thus, regardless which approach we take, it appears that DEUTSCHE, HSBC and OP are always selected as model banks.

Finally we also investigate the squared Mahalanobis distance between the average unit and the groups of bailed-out vis-a-vis non bailed-out banks in the funding-mix and asset-mix model in the pooled analysis.

Table 11: Squared Mahalanobis distance between groups, pooled analysis

\begin{tabular}{|c|c|c|c|c|c|c|}
\hline & \multicolumn{3}{|c|}{ Funding-mix model } & \multicolumn{3}{c|}{ Asset-mix model } \\
\hline & $\begin{array}{c}\text { non-bailed } \\
\text { NB }\end{array}$ & $\begin{array}{c}\text { bailed } \\
\text { B }\end{array}$ & average unit & $\begin{array}{c}\text { non-bailed } \\
\text { NB }\end{array}$ & $\begin{array}{c}\text { bailed (B) } \\
\text { B }\end{array}$ & average unit \\
\hline NB & 0 & & & 0 & & \\
B & 1.01 & 0 & & 1.38 & 0 & \\
average unit & 0.17 & 0.35 & 0 & 0.23 & 0.48 & 0 \\
\hline
\end{tabular}

Table 11 shows that the average unit (in the pooled analysis) is located closer to the group of non-bailed-banks than to the group of bailed-out banks in both models ${ }^{14}$. Thus one would expect that the weight restrictions have a larger impact on the group of bailed-out banks, resulting in a larger drop in efficiency scores for this group, as is indeed the case, c.f. Table 7 . Therefore the impact of weight restrictions based on the average unit, to some extent depend on the location of the average unit relative to the groups in question, rather than depending on how extreme the weights in the groups actually are. Therefore we here prefer the use of the average weights across facets, which furthermore are guaranteed to be unique and non-zero (unlike the weights for the average unit).

Finally, as yet another robustness checks, we have experimented with different widths of the ranges for the weight restrictions, in both models and under both approaches. We find that the width of the range does not affect the relative pattern between the bailed and non-bailed out banks identified above, but only impacts the absolute levels of the decreases in scores. Similarly we have experimented with using the median rather than the mean to define weight restrictions under the facet approach, and we find that whether we use median or average does not affect the relative pattern between the bailed and non-bailed-out banks.

\footnotetext{
${ }^{14}$ The calculation of Mahalanobis distance has also been carried out within each year and the pattern is the same as here.
} 


\section{Conclusion}

In performance assessments of banks using standard DEA models, extreme reliance on certain inputs and/or outputs will tend to make a bank efficient by default. This feature of DEA makes it unsatisfactory for evaluation of the performance of banks. The efficient functioning of a bank often implies risks: For example, the function of modern banks of providing transformation of funding with short maturities from depositors into securities with long maturities that borrowers desire, necessarily implies a risk. This means that risk is an inseparable element from bank efficiency. As demonstrated by the recent crisis, having extreme funding portfolios (especially heavy reliance on wholesale funding as opposed to retail funding) or extreme asset portfolios (especially wrt. property loan exposure) may be associated with excessive risk-taking, making it inappropriate to render these banks efficient by default. We therefore propose using a weight restricted DEA model for bank efficiency analysis, where the allowable weights are restricted to ranges determined by the average weights.

With a representative data set of over 70 of the largest banks in Europe, for the years 2006-2009, we estimate banks' efficiency in two sets of models: a funding mix model and an asset mix model both with and without weight restrictions. This enables us to understand potential risks associated specifically with extreme funding (and other input) portfolios and with(loan and) asset portfolios. In the funding mix model, banks transform wholesale funding, retail funding, personnel expenses, and physical capital expenses into loans and financial assets. In the asset mix model, banks transform property loans, non-property loans, trading financial assets and other financial assets into income (which includes both interest and non-interest income). In addition, we also control for loan quality and loan loss provision by including impaired loans as an input and provision for impaired loan loss as an output in the asset mix model, and use the impaired loans as an input in the funding mix model. The idea is to penalise bad management of problem loans and reward prudential perception in terms of loss provision set aside by banks. All data are collected from the audited financial reports of each bank individually, to ensure consistency in definition, coverage, and accuracy.

We show that the decreases in efficiency scores after weight restrictions are significantly higher for the bailed-out banks than for the non-bailed-out banks in the pooled analysis. Moreover, we show that amongst those who have the largest decreases in efficiency scores after weight restrictions, there is an over-representation of the bailed-out banks. These results confirm the bias arising from unrestricted DEA models of rewarding potentially risky banks with extreme asset and/or funding portfolios. We then conduct annual analysis to see whether the banks with the largest drops in efficiency scores after weight restrictions, especially in year 2006, are associated with those which fell into more serious trouble later during the crisis and needed bail-out. Our results confirm this. However for the remaining years, where the crisis had already started affecting at least some of the banks, we do not observe as clear a pattern between non-bailed and 
bailed-out banks in terms of drop in efficiency scores after weight restrictions in especially the funding mix model; in the asset mix model the bailed-out banks are already significantly less efficient then the non-bailed-out banks even before the imposition of weight restrictions. The results from 2007 in the annual analysis should perhaps be taken with caution due to the transitional change in market conditions. One may expect some banks to still be pursuing highly risky activities, whereas others may already have started to be more aware of the changes in the market conditions reacting to the difficulties experienced by certain banks in that year (such as Northern Rock in the UK).

Applying restrictions on the weights (which reflect banks' perception of risk adjusted prices of funding and assets) enables us to restrict heterogeneous bank risk judgements to belong to a certain range, determined by the average judgement. Based on the understanding of how the substantial heterogeneity in bank risk judgement can reduce the effectiveness of proposed risk benchmarks, such as the Basel regulatory capital ratios, we propose that our weight restricted DEA model, by restricting banks' risk judgement, can be used as a regulatory tool to select reference banks. The risk estimates of these banks can then be used to create reference points for risk parameters used to define regulatory capital benchmarks (i.e. the regulatory capital ratios). This way, the discretion in "risk weights" (inferred denominator of regulated capital ratios) will be constrained, thus improving the effectiveness of regulatory capital ratios as regulatory benchmarks ${ }^{15}$ We present a list of banks whose weight restricted scores in both the funding and the asset mix models are consistently above the 50th percentile with both pooled and annual analysis. Among all banks, DEUTSCHE, HSBC and OP are consistently selected as potential model banks whose internal risk estimates can be used to help regulators to determine reference risk parameters. Within a similar policy setting, the recent study by Knaup and Wagner (2012) proposes the use of market information (share price and credit default swap spread) to derive an index to estimate a "risk weight" for computing regulatory capital requirements. We posit that such tools, together with the one proposed in our study, that make use of different types of information, can complement each other to improve the effectiveness of bank capital supervision.

\footnotetext{
${ }^{15}$ Although the consequential adjustment of weights associated with different types of assets and funding by banks due to this supplementary regulatory tool might indirectly affect the composition of their funding- and asset portfolios, we believe that the practice of adjusting banks' extreme judgements regarding the risk-adjusted prices associated with different types of funding and assets should help to promote the stability of the system without which healthy and effective competition may not be possible.
} 


\section{References}

Aigner, D.J., Lovell, C.A.K. and Schmidt, P. (1977), Formulation and estimation of stochastic frontier production functions, Journal of Econometrics, 6, pp. 21-37.

Allen, R., Athanassopoulos, A., Dyson, R.G. and Thanassoulis, E. (1997), Weights restrictions and value judgements in data envelopment analysis: Evolution, development and future directions, Annals of Operations Research, 73, pp. 13-34.

Altunbas, Y., Gardener, E.P.M., Molyneux, P. and Moore, B. (2001), Efficiency in European banking, European Economic Review, 45, pp. 1931-1955.

Altunbas, Y., Carbo, S., Gardener, E.P.M. and Molyneux, P. (2007), Examining the relationships between capital, risk and efficiency in European banking, European Financial Management, 13, pp. 49-70.

Bank of England (2012), Financial Stability Report, No. 32, Bank of England

BIS (2010), Basel III: International Framework for Liquidity Risk Measurement, Standards, and Monitoring, Bank of International Settlements

BIS (2013), Regulatory Consistency Assessment Programme (RCAP): Analysis of riskweighted assets for credit risk in the banking book, Bank of International Settlements

Berg, S., Forsund, F. and Jansen, E.S. (1992), Malmquist indices of productivity growth during deregulation of Norwegian banking 1980-89, Scandinavian Journal of Economics, 94, pp. 211-28.

Berger A.N. (2007), International Comparisons of Banking Efficiency, Financial Markets, Institutions \& Instruments, 16, pp. 119- 144.

Berger, A. and Humphrey, D.B. (1997), Efficiency of financial institutions: International survey and directions for future research, European Journal of Operational Research, 98(2), pp. 175-212.

Berger, A.N., Saunders, A., Scalise, J.M. and Udell, G.F. (1997), The effects of bank mergers and acquisitions on small business lending, Discussion paper, Federal Reserve Board.

Bologna, P. (2011), Is There a Role for Funding in Explaining Recent U.S. Banks' Failures? IMF Working Paper WP/11/180.

Bryant, J. (1980), A Model of Reserves, Bank Runs, and Deposit Insurance, Journal of Banking and Finance, 4, pp. 335-344.

Brockett, P.L., Charnes, A., Cooper, W.W., Huang, Z.M. and Sun, D.B. (1997), Data transformations in DEA cone ratio envelopment approaches for monitoring bank performances, European Journal of Operational Research, 98, pp. 250-268.

Camanho, A.S. and Dyson, R.G. (2003), Cost efficiency measurement with price uncertainty: a DEA application to bank branch assessments, European Journal of Operational Research, 161, pp. 432-446.

Carvallo, O. and Kasman, A. (2005), Cost efficiency in the Latin American and Caribbean banking systems, International Financial Markets, Institutions and Money, 15, pp. 55-72.

Chang, C.C. (1999), The nonparametric risk-adjusted efficiency measurement: an application to Taiwan's major rural financial intermediaries, American Journal of Agricultural Economics, 81, pp. 902-13. 
Charnes, A., Cooper, W.W., Huang, Z.M. and Sun, D.B. (1990), Polyhedral cone-ratio DEA models with an illustrative application to large commercial banks, Journal of Econometrics, 46, pp. 73-91.

Charnes, A., Cooper, W.W. and Rhodes, E. (1978), Measuring the efficiency of decision making units, European Journal of Operational Research, 2, pp. 429-444.

Claessens, S., Dell'Ariccia, G., Igan, D. and Laeven, L. (2010), Cross-Country Experiences and Policy Implications from the Global Financial Crisis, Economic Policy, 25, pp. 267-293.

Coval, J., Jurek, J. and Stafford, E. (2009), The Economics of Structured Finance, The Journal of Economic Perspectives, 23 (1), pp. 3-26

Demirguc-Kunt, A. and Huizinga, H. (2009), Bank Activity and Funding Strategies: The Impact on Risk and Returns, World Bank Working Paper 4837, The World Bank.

Diamond, D.W. and Dybvig, P.H. (1983), Bank Runs, Deposit Insurance, and Liquidity, Journal of Political Economy, 91, pp. 401-419.

Diamond, D.W. and Rajan, R.G. (2001), Liquidity Risk, Liquidity Creation, and Financial Fragility: A Theory of Banking, Journal of Political Economy, 109, pp. 287-327.

Fiordelisi, F., Marques-Ibanez, D. and Molyneux, P. (2011), Efficiency and risk in European banking, Journal of Banking and Finance, 35, pp. 1315-1326.

FSA (2007), Banks, Large Corporates and Sovereigns HPE, Prudential Risk Division, Financial Services Authority UK, September.

FSA (2010), Results of 2009 Hypothetical Portfolio Exercise for sovereigns, banks and large corporations, Prudential Risk Division, Financial Services Authority UK, March

Haldane, A.G. (2013), Constraining discretion in bank regulation, speech given at the Federal Reserve Bank of Atlanta Conference on 'Maintaining Financial Stability: Holding a Tiger by the Tail(s)', Federal Reserve Bank of Atlanta 9 April 2013.

Holton, G. A. (2004), Defining Risk, Financial Analysts Journal, 60 (6), CFA Institute

Hughes, J.P. and Mester, L.J. (1993), A quality and risk-adjusted cost function for banks: Evidence on the 'too-big-to-fail' doctrine, Journal of Productivity Analysis, 4, pp. 293-315.

Hughes, J.P., Mester, L.J. and Moon, C.G. (2001), Are scale economies in banking elusive or illusive? evidence obtained by incorporating capital structure and risk-taking into models of bank production, Journal of Banking and Finance, 25, pp. 2169-2208.

Knaup, M. and Wagner, W. (2012), A Market-Based Measure of Credit Portfolio Quality and Banks' Performance During the Subprime Crisis, Management Science, 58 (8), pp. 1423-1437.

Koutsomanoli-Filippaki, A.I. and Mamatzakis, E.C. (2011), Efficiency under quantile regression: What is the relationship with risk in the EU banking industry?, Review of Financial Economics, 20, pp. 84-95.

Kuosmanen, T., Kortelainen, M., Sipilainen, T., Cherchye, L. (2010), Firm and industry level profit efficiency analysis using absolute and uniform shadow prices, European Journal of Operational Research, 202(2), pp. 584 - 594.

Kwan, S. and Eisenbeis, R. (1997), Bank risk, capitalization and operating efficiency, Journal of Financial Services Research, 12, pp. 117-131. 
Laeven, L. (1990), Risk and efficiency in East Asian banks, Policy research working paper, World Bank.

Meeusen, M. and van den Broeck, J. (1977), Efficiency Estimation from Cobb-Douglas Production Functions with Composed Error, International Economic Review, 18 (2), pp. $435-44$.

Olesen, O.B. and Petersen, N.C. (2003), Identification and Use of Efficient Faces and Facets in DEA, Journal of Productivity Analysis, 20, pp. 323-360.

Pastor, J.M. and Serrano, L. (2005), Efficiency, endogenous and exogenous credit risk in the banking systems of the euro area, Applied Financial Economics, 15, pp. 631-649.

Podinovski V. (2004), Production trade-offs and weight restrictions in data envelopment analysis, Journal of the Operational Research Society, 55, pp. 1311-1322.

Seiford, M.L. and Zhu, J. (1999), Profitability and Marketability of the Top 55 U.S. Commercial Banks, Management Science 45 (9), pp. 1270-1288.

Settlage, D.M., Preckel, P.V. and Settlage, L.A. (2009), Risk-adjusted efficiency and risk aversion in the agricultural banking industry, Agricultural Finance Review, 69, pp. 314-29.

Soteriou, A. and Zenios, S.A. (1999), Operations, Quality and Profitability in the provision of banking services, Management Science, 45 (9), pp. 1270-1288.

Thanassoulis, E. and Allen, R. (1998), Simulating Weights Restrictions in Data Envelopment Analysis by Means of Unobserved DMUs, Management Science, 44 (4), pp. 586-594.

Vazquez, F. and Federico, P. (2012), Bank Funding Structures and Risk: Evidence from the Global Financial Crisis, IMF working paper, WP/12/29.

Wanke, P., Barros, C. P. and Faria, J. R. (2014), Financial distress drivers in Brazilian banks: A dynamic slacks approach, European Journal of Operational Research, in Press.

Williams, J. (2004), Determining management behaviour in European banking, Journal of Banking and Finance, 28, pp. 2427-2460.

Wong, Y.-H.B. and Beasley, J.E. (1990). Restricting weight flexibility in data envelopment analysis, Journal of the Operational Research Society, 41, pp. 829-835.

Yildirim, S. and Philippatos, G. (2007), Efficiency of banks: Recent evidence from the transition economies of Europe 1993-2000, European Journal of Finance, 13, pp. 123-143. 


\section{Appendix}

Table 12: Variables used in the models

\begin{tabular}{|c|c|}
\hline Funding mix model & Asset mix model \\
\hline \multicolumn{2}{|c|}{ Input variables } \\
\hline retail funding expenses \\
wholesale funding expenses \\
physical capital expenses \\
$\begin{array}{c}\text { personnel expenses } \\
\text { impaired loan }\end{array}$ & property loan \\
non-property loan \\
trading financial assets \\
non-trading financial assets \\
impared loan \\
\hline loans & income \\
financial assets & provision for impaired loan loss \\
\hline
\end{tabular}

Table 13: List of banks included in the sample

\begin{tabular}{|c|c|c|c|c|}
\hline Bank & $\begin{array}{l}\text { Member } \\
\text { State }\end{array}$ & $\begin{array}{l}\text { Total Assets } \\
\text { by end of } \\
2009 \text { (EUR } \\
\text { bn) }\end{array}$ & $\begin{array}{l}\text { Market share } \\
\text { (total assets) } \\
\text { in EU-27 (\%) }\end{array}$ & $\begin{array}{l}\text { Far-reaching } \\
\text { restructuring }\end{array}$ \\
\hline ERSTE & Austria & 201.7 & 0.5 & $\mathrm{~N}$ \\
\hline RZB & Austria & 147.9 & 0.3 & $\mathrm{~N}$ \\
\hline BAWAG & Austria & 41.2 & 0.1 & $\mathrm{Y}$ \\
\hline Hypo Tirol & Austria & 12.2 & 0.0 & $\mathrm{Y}$ \\
\hline HGAA & Austria & 41.0 & 0.1 & $\mathrm{Y}$ \\
\hline $\mathrm{KBC}$ & Belgium & 281.6 & 0.7 & $\mathrm{Y}$ \\
\hline Dexia & Belgium & 577.6 & 1.3 & $\mathrm{Y}$ \\
\hline Fortis & Belgium & 435.0 & 1.0 & $\mathrm{Y}$ \\
\hline Marfin Popular & Cyprus & 41.8 & 0.1 & $\mathrm{~N}$ \\
\hline Bank of Cyprus (BoC) & Cyprus & 39.4 & 0.1 & $\mathrm{~N}$ \\
\hline DANSKE & Denmark & 416.3 & 1.0 & $\mathrm{~N}$ \\
\hline JYSKE & Denmark & 30.2 & 0.1 & $\mathrm{~N}$ \\
\hline SYDBANK & Denmark & 21.2 & 0.0 & $\mathrm{~N}$ \\
\hline OP-Pohjola (OP) & Finland & 80.4 & 0.2 & $\mathrm{~N}$ \\
\hline BNP Paribas & France & 2057.7 & 4.8 & $\mathrm{~N}$ \\
\hline $\mathrm{BPCE}$ & France & 1028.8 & 2.4 & Y \\
\hline Credit Agricole & France & 1694 & 3.9 & $\mathrm{~N}$ \\
\hline Societe Generale (SG) & France & 1023.7 & 2.4 & $\mathrm{~N}$ \\
\hline Deutsche & Germany & 1501 & 3.5 & $\mathrm{~N}$ \\
\hline Commerzbank & Germany & 844.1 & 2.0 & $\mathrm{Y}$ \\
\hline Hypo Real Estate & Germany & 359.7 & 0.8 & $\mathrm{Y}$ \\
\hline LBBW & Germany & 411.7 & 1.0 & $\mathrm{Y}$ \\
\hline NordLB & Germany & 238.7 & 0.6 & $\mathrm{Y}$ \\
\hline WestLB & Germany & 242.3 & 0.6 & $\mathrm{Y}$ \\
\hline HSH Nordbank & Germany & 174.5 & 0.4 & $\mathrm{Y}$ \\
\hline
\end{tabular}


Table 13: List of banks included in the sample

\begin{tabular}{|c|c|c|c|c|}
\hline Bank & $\begin{array}{l}\text { Member } \\
\text { State }\end{array}$ & $\begin{array}{l}\text { Total Assets } \\
\text { by end of } \\
2009 \text { (EUR } \\
\text { bn) }\end{array}$ & $\begin{array}{l}\text { Market share } \\
\text { (total assets) } \\
\text { in EU-27 (\%) }\end{array}$ & $\begin{array}{l}\text { Far-reaching } \\
\text { restructuring }\end{array}$ \\
\hline NBoG & Greece & 113.4 & 0.3 & $\mathrm{~N}$ \\
\hline EFGEurobank (EFG) & Greece & 84.3 & 0.2 & $\mathrm{~N}$ \\
\hline Alpha & Greece & 69.6 & 0.2 & $\mathrm{~N}$ \\
\hline Piraues & Greece & 54.3 & 0.1 & $\mathrm{~N}$ \\
\hline ATE & Greece & 32.8 & 0.1 & $\mathrm{Y}$ \\
\hline TT Hellenic Postbanks & Greece & 18.0 & 0.0 & $\mathrm{~N}$ \\
\hline OTP & Hungary & 36.1 & 0.1 & $\mathrm{~N}$ \\
\hline FHB & Hungary & 3.0 & 0.0 & $\mathrm{~N}$ \\
\hline BoI & Ireland & 194.1 & 0.5 & $\mathrm{Y}$ \\
\hline Allied Irish Bank & Ireland & 174.3 & 0.4 & $\mathrm{Y}$ \\
\hline Anglo Irish Bank & Ireland & 85.2 & 0.2 & $\mathrm{Y}$ \\
\hline UniCredit & Italy & 928.8 & 2.2 & $\mathrm{~N}$ \\
\hline Intesa Sanpaolo & Italy & 624.8 & 1.5 & $\mathrm{~N}$ \\
\hline Monte dei Pasche di Siena & Italy & 224.8 & 0.5 & $\mathrm{~N}$ \\
\hline BPSC & Italy & 135.7 & 0.3 & $\mathrm{~N}$ \\
\hline UBI & Italy & 122.3 & 0.3 & $\mathrm{~N}$ \\
\hline BCEE & Luxembourg & 37.6 & 0.1 & $\mathrm{~N}$ \\
\hline ING & Netherlands & 882.1 & 2.1 & $\mathrm{Y}$ \\
\hline $\mathrm{RABO}$ & Netherlands & 607.7 & 1.4 & $\mathrm{~N}$ \\
\hline ABN AMRO & Netherlands & 676.3 & 1.6 & $\mathrm{Y}$ \\
\hline $\mathrm{FBN}$ & Netherlands & 189.8 & 0.4 & $\mathrm{Y}$ \\
\hline SNS & Netherlands & 80.3 & 0.2 & $\mathrm{Y}$ \\
\hline $\mathrm{BoV}$ & Malta & 6.2 & 0.0 & $\mathrm{~N}$ \\
\hline $\mathrm{PKO}$ & Poland & 38.1 & 0.1 & $\mathrm{~N}$ \\
\hline CGD & Portugal & 105.8 & 0.2 & $\mathrm{~N}$ \\
\hline $\mathrm{BCP}$ & Portugal & 95.6 & 0.2 & $\mathrm{~N}$ \\
\hline Espirlto Santo & Portugal & 78.1 & 0.2 & $\mathrm{~N}$ \\
\hline BPI & Portugal & 47.4 & 0.1 & $\mathrm{~N}$ \\
\hline NLB & Slovenia & 15.5 & 0.0 & $\mathrm{~N}$ \\
\hline Santander & Spain & 1110.5 & 2.6 & $\mathrm{~N}$ \\
\hline BBVA & Spain & 535.1 & 1.2 & $\mathrm{~N}$ \\
\hline LA Caixa & Spain & 271.9 & 0.6 & $\mathrm{~N}$ \\
\hline Caixa Catlunya & Spain & 63.7 & 0.1 & $\mathrm{Y}$ \\
\hline Caixa Tarragona & Spain & 10.8 & 0.0 & $\mathrm{Y}$ \\
\hline Caixa Manresa & Spain & 6.5 & 0.0 & $\mathrm{Y}$ \\
\hline Caixa Navarra & Spain & 19.5 & 0.0 & $\mathrm{Y}$ \\
\hline CajaSur & Spain & 19.0 & 0.0 & $\mathrm{Y}$ \\
\hline Nordea & Sweden & 507.5 & 1.2 & $\mathrm{~N}$ \\
\hline SEB & Sweden & 225.1 & 0.5 & $\mathrm{~N}$ \\
\hline SB & Sweden & 207.1 & 0.5 & $\mathrm{~N}$ \\
\hline Swedbank (SWED) & Sweden & 175.1 & 0.4 & $\mathrm{~N}$ \\
\hline RBS & UK & 1714.3 & 4.0 & $\mathrm{Y}$ \\
\hline HSBC & UK & 1641.3 & 3.8 & $\mathrm{~N}$ \\
\hline
\end{tabular}


Table 13: List of banks included in the sample

\begin{tabular}{|c|c|c|c|c|}
\hline Bank & $\begin{array}{l}\text { Member } \\
\text { State }\end{array}$ & $\begin{array}{l}\text { Total Assets } \\
\text { by end of } \\
2009 \text { (EUR } \\
\text { bn) }\end{array}$ & $\begin{array}{l}\text { Market share } \\
\text { (total assets) } \\
\text { in EU-27(\%) }\end{array}$ & $\begin{array}{l}\text { Far-reaching } \\
\text { restructuring }\end{array}$ \\
\hline Barclays (BARC) & UK & 1552.7 & 3.6 & $\mathrm{~N}$ \\
\hline Lloyds banking group & UK & 1156.7 & 2.7 & $\mathrm{Y}$ \\
\hline Northern Rock(NR) & UK & 98.5 & 0.2 & $\mathrm{Y}$ \\
\hline Total & EU-27 & 27021.2 & & \\
\hline $\begin{array}{l}\text { Accumulative } \\
\text { share }(\%)\end{array}$ & EU-27 & & 63.0 & \\
\hline \multicolumn{5}{|c|}{$\begin{array}{l}\text { a. Total assets include total loans, financial assets and fixed assets, calculated based on data } \\
\text { from banks' audited financial statements. } \\
\text { b. Total assets of the EU banking system is from ECB. }\end{array}$} \\
\hline
\end{tabular}




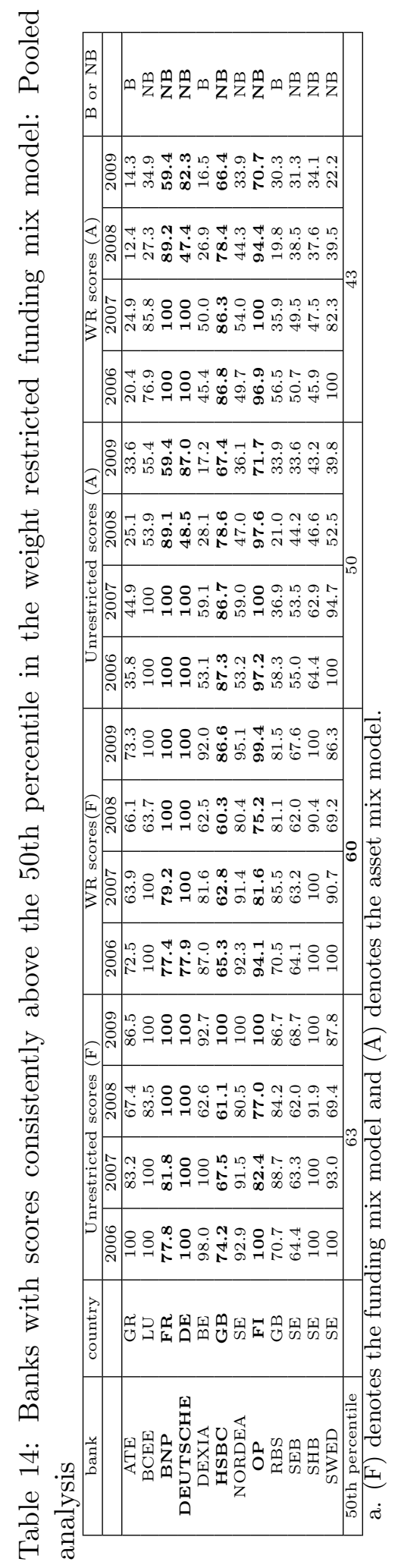




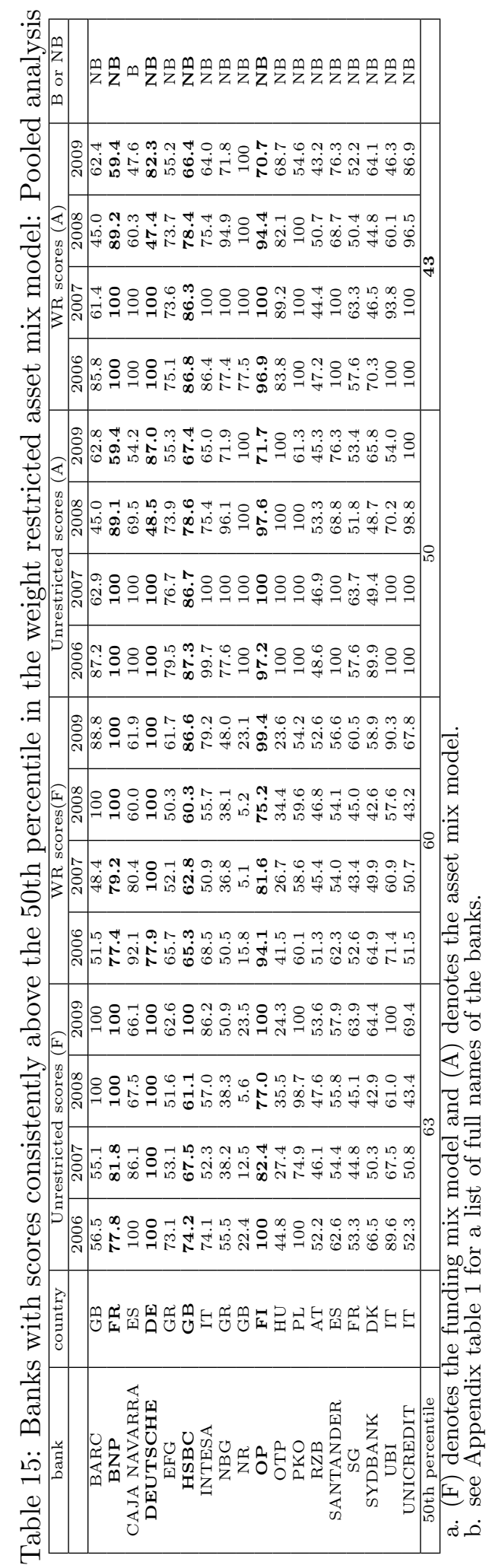




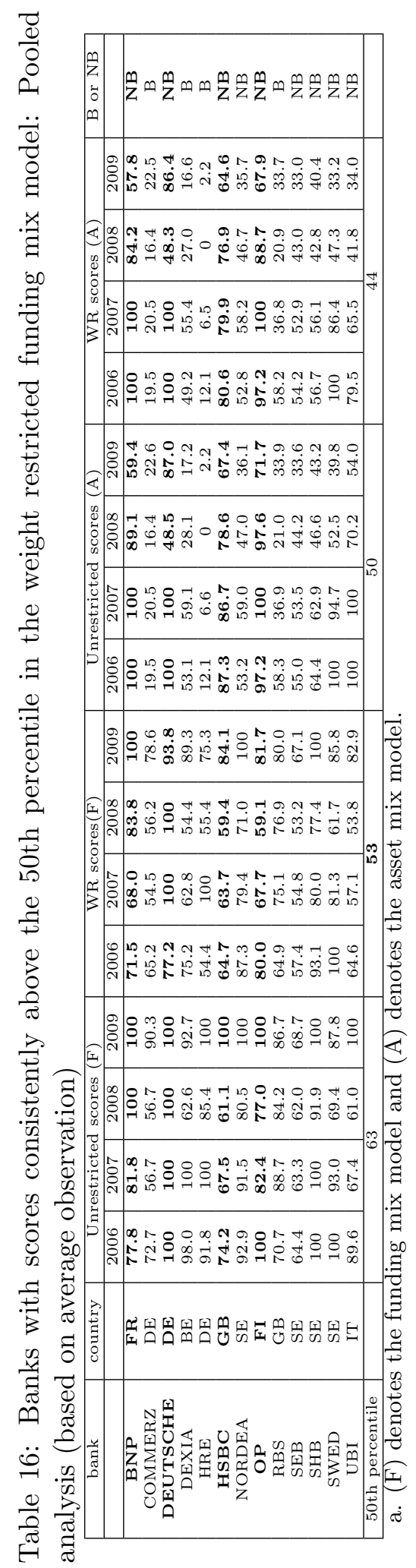




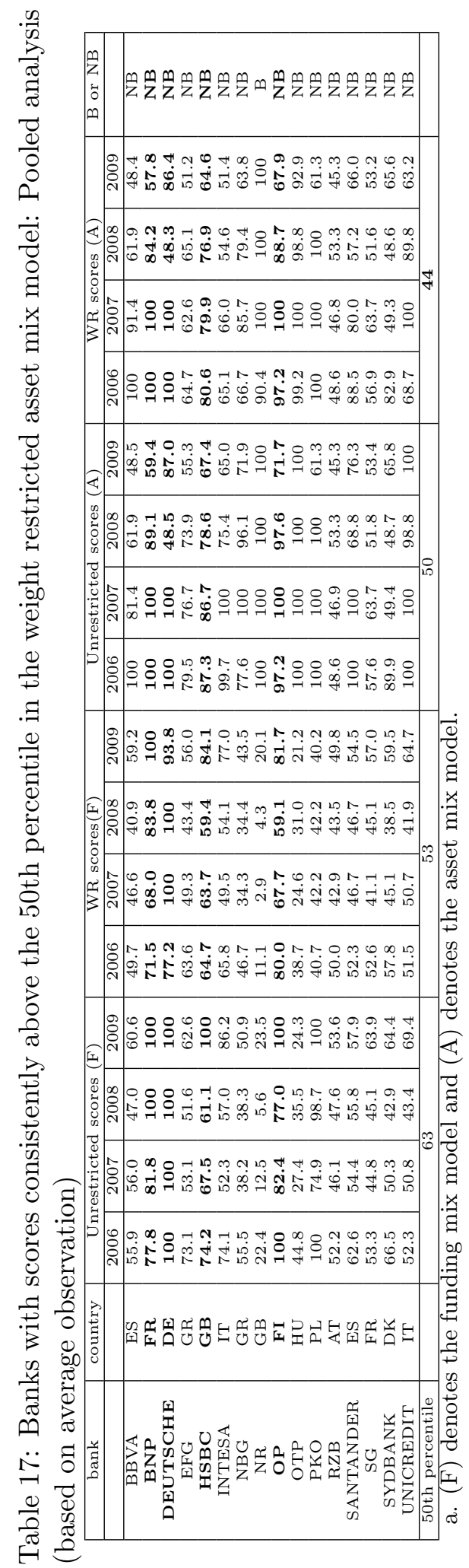

